\title{
I. Systematic Index
}

\section{Primates}

\section{Generalities}

Recent and Current Field Studies of Primates. De Vore, I. and Lee, R. 1 (1): 66-72 (1963).

Sensitivity to P.T.C. (Phenyl-Thio-Carba-mide) in Primates. Chiarelli, B. 1 (2): 88-94 (1963).

The Functional Significance of the Deep Head of Flexor pollicis brevis in Primates. Day, M.H. and Napier, J. 1 (2): 122-134 (1963).

Relations Between the Lengths of the Main Parts of the Foot Skeleton in Primates. Schultz, A.H. 1 (3-4): 150-171 (1963).

Das Serumeiweissbild der Primaten unter besonderer Berücksichtigung der Hap-toglobine und Transferrine. Lange, V. und Schmitt, J. 1 (3-4): 208-250 (1963).

The Study of Social Behavior in Primates. Plutchik, R. 2 (2): 67-92 (1964).

Der Canalis sacralis als Indikator für die Länge der Caudalregion der Primaten. Ankel, F. 3

(4): 263-276 (1965).

Über die Zentralisation der Retina bei Primaten. Rohen, J.W. und Castenholz, A. 5 (1-2): 92147 (1967).

The Anatomical and Histochemical Properties of the Tongue of Primates.

Machida, H.; Perkins, E., and Giaco-metti, L. 5 (4): 264-279 (196).

The Anatomical and Histochemical Properties on the Skin of the External Geni-talia of the Primates. Machida, H. and Giacometti, L. 6 (1-2): 48-69 (1967).

Angular Growth Changes and Comparisons in the Primate Talus. Lisowski, F.P. 7 (2): 81-97 (1967).

Urate Oxidase in Primates. Christen, P.; Peacock, W.C.; Christen, A.E., and Wacker, W.E.C. 13 (1): 35-39 (1970).

The Histology of the Primate Urethra. Roberts, J.A. and Seibold, H.R. 14 (1-2): 59-69 (1971). Comparative Biochemistry of the Primates.

I. Amino Acid Patterns in the Blood and

Urine. Smith, I. 14 (1-2): 101-109

(1971).

Comparative Biochemistry of the Primates.

II. The Indole Compounds of Primate

Blood and Urine. Smith, I. and Lerner,

R.P. 14(1-2): 110-117(1971).

Die phylogenetische Entwicklung der Hüft-und Oberschenkelmuskulatur der Primaten.

Uhlmann, K. 15 (1-2): 88-116 (1971).

A Comparative Study of the Superior Olivary Complex in the Primate Brain. Moore, J.K. and Moore, R.Y. 16 (1-2): 35-51 (1971).

Survival, Mating and Rearing Strategies in

242

A Topical Guide to 'Folia Primatologica' 
the Evolution of Primate Social Structure. Goss-Custard, J.D.; Dunbar, R.I.M., and AldrichBlake, F.P.G. 17 (1-2): 1-19 (1972).

Hour of Birth in Primates and Man. Jolly, A. 18(1-2): 108-121(1972).

Tendances locomotrices des primates tra-duites par les proportions du pied. L'adaptation à la bipédie. Lessertisseur, J. et Jouffroy, F.K. 20 (2-3): 125-160 (1973).

Maternal-Fetal Weight Relationships in Primates. Leutenegger, W. 20 (4): 280-293 (1973).

Cladistic Relationships among Primate Higher Categories: Evidence of the Fetal Membranes and Placenta. Luk-kett, W.P. 25 (4): 245-276 (1976).

Erythroblastosis Models. II. Materno-Fetal Incompatibility in Chimpanzee. Wiener, A.S.;

Socha, W.W., and Moor-Jan-kowski, J. 27 (1): 68-74 (1977).

Nest and Home. Hediger, H. 28 (3): 170-187 (1977).

The Taste Responses in Primates to the Proteins Thaumatin and Monellin and their

Phylogenetic Implications. Gla-ser, D.; Hellekant, G.; Brouwer, J.N., and Wel, H. van der. 29 (1): 56-63 (1978).

Nonhuman primates

Artherosclerosis in Subhuman Primates. Malinow, M.R. 3 (4): 277-300 (1965).

Colobomas in Non-human Primates. Schmidt, R.E. 14 (3-4): 256-268 (1971).

Serological Reactions with Treponemal Antigens in Nonhuman Primates and the Natural

History of Treponematosis in Man. Felsenfeld, O. and Wolf, R.H. 16 (3^1): 294-305 (1971).

Spatial Factors and the Behavior of Non-human Primates. Wilson, C.C. 18 (3-4): 256-275

(1972).

The Topography of the Premaxillary-

Frontal Region in Nonhuman Primates.

Swindler, D.R. and Tarrant, L.H.

19(1): 18-23 (1973). Effects of Testosterone on Status in Primate

Groups. Mazur, A. 26 (3): 214-226

(1976).

Prosimii

The Structure of the AUantoic Placenta of the Senegal Bush Baby (Galago senega-lensis senegalensis). Butler, H. and Adam, K.R. 2 (1): 22-49 (1964).

Hematology of Prosimian Primates: Galago, Lemur and Propithecus. Bergeron, J.A. and

Buettner-Janusch, J. 13 (2-3): 155-165 (1970).

Properties of the Hemoglobins of Newborn and Adult Prosimians (Prosimii: Le-muriformes and Lorisiformes). Buettner-Janusch, J.; Buettner-Janusch, V., and Coppenhaver, D. 17 (3): 177-192 (1972).

Immunodiifusion Systematics of the Primates. III. The Strepsirhini. Dene, H.; Goodman, M.; Prychodko, W., and Moore, G.W. 25 (1): 35-61 (1976).

The Taste Responses in Primates to the Proteins Thaumatin and Monellin and their

Phylogenetic Implications. Gla-ser, D.; Hellekant, G.; Brouwer, J.N., and Wel, H. van der. 29 (1): 56-63 (1978).

Tupaiiformes

Tupaiidae

Observations on the Social Behavior of Tree Shrews in Captivity. Sorenson, M.W. and Conaway, C.H. 4 (2): 124-145 (1966).

The Gross and Microscopic Anatomy of the Uterus masculinus of Tree Shrews. 
Systematic Index

243

Alcalá, J.R. and Conaway, C.H. 9 (3-4): 216-245 (1968).

The Neuroanatomical Organization of the Visual System in the Tree Shrew. Ab-planalp, P. 16 (1-2): 1-34 (1971).

A Comparative Histochemical Study of the Mucins of the Nasal Fossa in Four Primates. Loo, S. K.; Kanagasuntheram, R., and Tock, E.P.C. 17 (4): 275-284 (1972).

Untersuchungen über die Geschmackswir-kung von Phenylthiocarbamid (PTC) bei Primaten. Glaser, D. 18 (1-2): 27-34 (1972).

Die Reaktion bei einigen Primaten auf zwei künstliche Süssstoffe und $7 / 8 \mathrm{O}$ dest. Glaser, D. 18 (5-6): 433-443 (1972).

Tupaia glis

Feeding, Activity and Social Behavior of the Tree Shrew, Tupaia glis, in a Large Outdoor

Enclosure. Vandenbergh, J. G. 1(3-4): 199-207 (1963).

On Visual Learning Capacity, Retention and Memory in Tupaia glis Diard 1820. Tigges, J. 2 (4): 232-245 (1964).

Studies on the Behavior of Captive Tree Shrews (Tupaia glis). Kaufmann, J.H. 3(1): 50-74 (1965).

Zur Ontogenese der Bulla tympanica von Tupaia glis Diard 1820 (Prosimiae, Tu-paiiformes). Spatz, W.B. 4 (1): 26-50 (1966).

Ein experimenteller Beitrag zum subkorti-kalen optischen System von Tupaia glis. Tigges, J. 4 (2): 103-123 (1966).

Color Vision in the Tree Shrew (Tupaia glis). Shriver, J. E. and Noback, C. R. 6 (3-4): 161169 (1967).

Die Ontogenese der Cartilago meckeli und der Symphysis mandibularis bei Tupaia glis

(Diard, 1820). Die distale Verknö-cherung des Meckelschen Knorpels als funktionelle

Anpassung an den Saug-

akt. Spatz, W.B. 6 (3-4): 180-203 (1967).

The Hemogram of the Tree Shrew (Tupaia glis). Hunt, R.D. and Chalifoux, L. 7(1): 34-36

(1967).

Chromosome Dimorphism in Primates. Egozcue, J. 7 (3-4): 231-237 (1967).

Position of the Centromere in the Marked Acrocentric Chromosomes of Primates. Egozcue, J. 7 (3-4): 238-242 (1967).

Chromosome Polymorphism in the Tree Shrew (Tupaia glis). Egozcue, J.; Chiarelli, B.; SartiChiarelli, M., and Hagemenas, F. 8 (2): 150-158 (1968).

The Gross and Microscopic Anatomy of the Uterus masculinus of Tree Shrews. Alcalá, J.R. and Conaway, C.H. 9 (3-4): 216-245 (1968).

Histologische und vergleichend-anatomi-sche Untersuchungen zur Ontogenie und Phylogenie des Handskeletts von Tupaia glis (Diard 1820) und Micro-cebus murinus (J.F. Miller 1777).

Alt-ner, G. 14 (Suppl.): 1-106 (1971).

The Nasal Fossa of Tupaia glis and Nycti-cebus coucang. Loo, S.K. and Kanagasuntheram, R. 16 (1-2): 74-84 (1971).

The Intrinsic Adrenergic and Cholinergic Innervation of the Genitalia of Galago and Tupaia. The Penis. Dail, W.G.; Norvell, J.E., and Harnes, D.E. 16 (3-4): 221-230 (1971). 
Vergleichende Untersuchungen über den Geschmackssinn der Primaten. Glaser, D. 17 (4): 267-274 (1972).

Zur Morphologie und Histologie des Ge-ruchsorgans von Tupaia glis (Diard 1820). Meinel, W. und Woehrmann-Repenning, A. 20 (4): 294-311 (1973).

A Comparative Study of the Nasal Fossa of Four Nonhuman Primates. Loo, S.K. 20 (5-6): 410-422 (1973).

Comparative Study of the Histology of the Nasal Fossa in Four Primates. Loo, S.K. 21 (3-4): 290-303 (1974).

244 A Topical Guide to

A Comparative Study on the Microscopic Anatomy of the Sublingua of Tupaia glis

(Tupaiiformes). Hofer, H. and Meinel, W. 26 (3): 229-243 (1976).

T. tana

Observations on the Social Behavior of Tree Shrews in Captivity. Sorenson, M.W. and

Conaway, C.H. 4 (2): 124-145 (1966).

The Gross and Microscopic Anatomy of the Uterus masculinus of Tree Shrews. Alcalá, J.R. and Conaway, C.H. 9 (3-4): 216-245 (1968).

T.palawanensis

Antiphonal Calling of the Tree Shrew Tupaia palawanensis. Williams, H.W., Sorenson,

M.W. and Thompson, P. 11 (3): 200-205 (1969).

Urogale everetti

The Gross and Microscopic Anatomy of

the Uterus masculinus of Tree Shrews.

Alcalá, J.R. and Conaway, C.H. 9

(3-4): 216-245 (1968). Zur Variabilität von Urogale everetti.

Angst, R. und Mann, P. 15 (1-2): 148-

158(1971).

Lemuriformes

Vertical Clinging and Leaping - a Newly Recognized Category of Locomotor Behaviour of Primates. Napier, J.R. and Walker, A.C. 6 (3-4): 204-219 (1967).

The Stability of Territorial Boundaries in a Lemur Troop. Klopfer, P.H. and Jolly, A. 12 (3): 199-208 (1970).

Hematology of Prosimian Primates: Ga-

'Folia Primatologica'

lago, Lemur and Propithecus. Bergeron, J.A. and Buettner-Janusch, J. 13 (2-3): 155-165

(1970).

Troop Continuity and Troop Spacing in Propithecus verreauxi and Lemur catta at Berenty (Madagascar). Jolly, A. 17 (5-6): 335-362 (1972).

Besonderheiten an der Gesichtsmuskulatur von Daubentonia madagascariensis (Gmelin 1788). Seiler, R. 22 (2-3): 81-96 (1974).

Immunodiffusion Systematics of the Primates. III. The Strepsirhini. Dene, H.; Goodman, M.; Prychodko, W., and Moore, G.W. 25 (1): 35-61 (1976).

Why Did the Strepsirhine Tooth Comb Evolve? Szalay, F.S. and Seligsohn, D. 27(1): 75-82 (1977).

Ontogeny of the Ectotympanic-Petrosal Plate Relationship in Strepsirhine Pro-simians.

MacPhee, R.D.E. 27 (4): 245-283 (1977). 
The Orbital Mosaic in Prosimians and the Use of Variable Traits in Systematics. Cartmill, M. 30 (2): 89-114 (1978).

Lemuridae

Vertical Clinging and Leaping - a Newly Recognized Category of Locomotor Behaviour of Primates. Napier, J.R. and Walker, A.C. 6 (3-4): 204-219 (1967).

Position of the Centromere in the Marked Acrocentric Chromosomes of Primates. Egozcue, J. 7 ( $\left.3^{\wedge}\right): 238-242$ (1967).

Genetics of Polymorphic Transferrins in the Genus Lemur, Nute, P.E. and Buettner-Janusch, J. 10 (3): 181-194 (1969).

The Stability of Territorial Boundaries in a Lemur Troop. Klopfer, P.H. and Jolly, A. 12 (3): 199-208 (1970).

Hematology of Prosimian Primates. II. A Comparative Study of Lemuriformes in Captivity in Madagascar and North Carolina. Bergeron, J.A. and Buett-

Systematic Index

245

ner-Janusch, J. 13 (4): 306-313 (1970). The Chromosomes of Lemurs. Egozcue, J.

17(3): 171-176(1972). Phylogeny of Lemurs, Galagos and Lorises.

Szalay, F.S. and Katz, C.C. 19 (2-3):

88-103 (1973). Composition of Lemur Milk. Buss, D. H.;

Cooper, R.W., and Wallen, K. 26 (4):

301-305 (1976).

Lemurinae

Hematology of Prosimian Primates. II. A Comparative Study of Lemuriformes in Captivity in Madagascar and North Carolina. Bergeron, J.A. and Buett-ner-Janusch, J. 13 (4): 306-313

(1970).

Learning: A Comparative Study of Lemur and Cercopithecus. Rumbaugh, D.M. and Arnold, R.C. 14 (3-4): 154-160 (1971).

Extinction: A Comparative Primate Study of Lemur and Cercopithecus. Arnold, R.C. and Rumbaugh, D.M. 14 (3-4): 161-170(1971).

The Chromosomes of Lemurs. Egozcue, J. 17(3): 171-176(1972).

Besonderheiten an der Gesichtsmuskulatur von Daubentonia madagascariensis (Gmelin 1788). Seiler, R. 22 (2-3): 81-96 (1974).

Lemur variegatus

A Comparison of the Reproductive Cycle of Three Species of Lemur. Bogart, M.H.;

Kumamoto, A.T., and Lasley, B.L. 28(2): 134-143(1977).

Aspects of Reproduction in Ruffed Lemurs (Lemur variegatus). Boskoff, K.J. 28 (4): 241-250 (1977).

Middle Ear Morphology of Lemur variegatus. Some Implications for Primate Paleontology.

Conroy, G. C. and Wible, J.R. 29 (2): 81-85 (1978).

L. catta

Genetics of Polymorphic Transferrins in the Genus Lemur. Nute, P.E. and Buett-ner-Janusch, J. 10 (3): 181-194 (1969).

The Stability of Territorial Boundaries in a Lemur Troop. Klopfer, P.H. and Jolly, A. 12 (3): 199-208 (1970). 
Troop Continuity and Troop Spacing in Propithecus verreauxi and Lemur catta at Berenty (Madagascar). Jolly, A. 17 (5-6): 335-362(1972).

Primate Breeding Season: Photoperiodic Regulation in Captive Lemur catta. Van Horn, R.N. 24 (2-3): 203-220 (1975).

Olfactory and Visual Cues in Social Interactions of Lemur catta. Mertl, A.S. 26 (2): 151-161 (1976).

Composition of Lemur Milk. Buss, D. H.; Cooper, R. W., and Wallen, K. 26 (4): 301-305

(1976).

A Comparison of the Reproductive Cycle of Three Species of Lemur. Bogart, M.H.;

Kumamoto, A.T., and Lasley, B.L. 28 (2): 134-143(1977).

L. macaco

Genetics of Polymorphic Transferrins in

the Genus Lemur. Nute, P.E. and

Buettner-Janusch, J. 10 (3): 181-194

(1969). The Stability of Territorial Boundaries in a

Lemur Troop. Klopfer, P.H. and

Jolly, A. 12 (3): 199-208 (1970). Composition of Lemur Milk. Buss, D.H.;

Cooper, R. W., and Wallen, K. 26 (4):

301-305 (1976). Why Did the Strepsirhine Tooth Comb

Evolve? Szalay, F.S. and Seligsohn,

D. 27(1): 75-82 (1977). A Comparison of the Reproductive Cycle of

Three Species of Lemur. Bogart, M. H.;

Kumamoto, A.T., and Lasley, B.L. 28

(2): 134-143 (1977).

246

A Topical Guide to 'Folia Primatologica'

Development of Behavior in Lemur macaco in the First Nineteen Weeks. Harrington, J.E. 29 (2): 107-128 (1978).

Diurnal Behavior of Lemur mongoz at Ampijoroa, Madagascar. Harrington, J.E. 29 (4): 291302 (1978).

L. mongoz

Tuberculosis in Lemur mongoz. Knezevic, A. L. and McNulty, W. P. 6 (1-2): 153-159(1967). Cycles of Activity, Group Composition, and Diet of Lemur mongoz mongoz Linnaeus 1766 in Madagascar. Sussman, R.W. and Tattersall, I. 26 (4): 270-283 (1976).

Diurnal Behavior of Lemur mongoz at Ampijoroa, Madagascar. Harrington, J.E. 29 (4): 291302 (1978).

Karyotype Abnormalities in Two Primate Species, Pygathrix nemaeus and Lemur coronatus. Bogart, M.H. and Kuma-moto, A.T. 30 (2): 152-160 (1978).

Cheirogaleinae

Hematology of Prosimian Primates. II. A Comparative Study of Lemuriformes in Captivity in Madagascar and North Carolina. Bergeron, J.A. and Buett-ner-Janusch, J. 13 (4): 306-313 (1970).

Immunodiiffusion Systematics of the Primates. III. The Strepsirhini. Dene, H.; Goodman, M.; Prychodko, W., and Moore, G.W. 25 (1): 35-61 (1976). 
Why Did the Strepsirhine Tooth Comb Evolve? Szalay, F.S. and Seligsohn, D. 27(1): 75-82 (1977).

Cheirogaleus major

Congenital Abnormalities of the Urinary Tract in Primates. Hill, W. C. Osman. 2(2): 111-

118(1964).

Microcebus murinus

Existence probable d'un rythme métabo-lique saisonnier chez les Cheirogaleinae

(Lemuroidea). Bourlière, F. et Petter-Rousseaux, A. 4 (4): 249-256 (1966).

Histologische und vergleichend-anatomi-sche Untersuchungen zur Ontogenie und Phylogenie des Handskeletts von Tupaia glis (Diard 1820) und Microcebus murinus (J.F. Miller 1777). Altner, G. 14 (Suppl.): 1-106 (1971).

Patterns of Activity in Three Nocturnal Prosimian Species, Galago senegalensis moholi, G. crassicaudatus umbrosus, and Microcebus murinus murinus, under Semi-Natural Conditions. Pinto, D.; Doyle, G.A., and Bearder, S.K. 21 (2): 135-147 (1974).

Indriidae

Vertical Clinging and Leaping - a Newly Recognized Category of Locomotor Behaviour of Primates. Napier, J.R. and Walker, A.C. 6 (3-4): 204-219 (1967).

The Stability of Territorial Boundaries in a Lemur Troop. Klopfer, P.H. and Jolly, A. 12 (3): 199-208 (1970).

Propithecus verreauxi

Troop Continuity and Troop Spacing in Propithecus verreauxi and Lemur catta at Berenty (Madagascar). Jolly, A. 17 (5-6): 335-362 (1972).

Intra-Specific Variation in the Social Organization and Ecology of Propithecus verreauxi. Richard, A. 22 (2-3): 178-207 (1974).

Why Did the Strepsirhine Tooth Comb Evolve? Szalay, F.S. and Seligsohn, D. 27(1): 75-82 (1977).

Systematic Index

247

The Birth and Early Development of a Captive Sifaka, Propithecus verreauxi coquereli.

Eaglen, R.H. and Boskoff, K.J. 30 (3): 206-219 (1978).

Daubentoniidae

Persistance des phénomènes d'ovogénèse chez Tadulte de Daubentonia mada-gascariensis (Prosimii, Lemuriformes). Petter-Rousseaux, A. et Bourlière, F. 3 (4): 241-244 (1965). Besonderheiten an der Gesichtsmuskulatur von Daubentonia madagascariensis (Gmelin 1788). Seiler, R. 22 (2-3): 81-96 (1974).

Lorisiformes

Lorisidae

Les chances primatologiques de ГEst-Afri-cain. Bone, E.L. 2 (1): 1-21 (1964).

The Structure of the Allantoic Placenta of the Senegal Bush Baby (Galago senega-lensis senegalensis). Butler, H. and Adam, K.R. 2 (1): 22-49 (1964).

Food-Motivated Behavior in Prosimians. Ehrlich, A. 8 (1): 66-71 (1968).

Activity Levels in Prosimians. Ehrlich, A. 8(1): 72-76 (1968).

Notes on Ecological Relationships of Four Species of Lorisids in Rio Muni, West Africa. Jones, C. 11 (4): 255-267 (1969). 
Nerve Terminations in the Digital Skin of the Hand in Some Lorisoids. Kanaga-suntheram, R.; Krishnamurti, A., and Ahmed, M. 12 (1): 42-55 (1970).

Glucose Preferences in the Greater Galago (Galago crassicaudatus) and Slow Loris

(Nycticebus coucang). Fobes, J.L. and Ehrlich, A. 16 (3-4): 306-311 (1971).

Untersuchungen über die Geschmackswir-kung von Phenylthiocarbamid (PTC)

bei Primaten. Glaser, D. 18 (1-2): 27 -

34 (1972). Notes on the Ecology of Five Lorisiformes

of Rio Muni. Sabater Pi, J.: 18 (1-2):

140-151 (1972). Die Reaktion bei einigen Primaten auf zwei

künstliche Süssstoffe und $7 / 8 \mathrm{O}$ dest.

Glaser, D. 18 (5-6): 433-443 (1972). Ontogeny of the Ectotympanic-Petrosal

Plate Relationship in Strepsirhine Prosimians. MacPhee, R.D.E. 27 (4):

245-283 (1977). The Orbital Mosaic in Prosimians and the

Use of Variable Traits in Systematics.

Cartmill, M. 30 (2): 89-114 (1978).

Lorisinae

Vergleichende Untersuchungen über den

Geschmackssinn der Primaten. Glaser,

D. 17 (4): 267-274 (1972). Phylogeny of Lemurs, Galagos and Lorises.

Szalay, F.S. and Katz, C.C 19 (2-3):

88-103 (1973). Die Fazialismuskeln von Perodicticus potto

und Nycticebus coucang. Seiler, R. 23

(4): 275-289 (1975).

Loris tardigradus

Changes in the Male Reproductive Organs of Loris tardigradus lydekkerianus (Cabrera).

Ramakrishna, P. A. and Pra-sad, M.R.N. 5 (3): 176-189 (1967).

Structure of the Pituitary Gland and Cyto-physiology of the Adenohypophysis in the Slender

Loris tardigradus lydekkerianus Cabr. Kumar, T.C. A. 6 (3^4): 220-235 (1967).

Nycticebus coucang

The External Morphology of the Brain of the Slow Loris Nycticebus coucang

248 A Topical Guide to

coucang. Krishnamurti, A. 4 (5): 361-380 (1966).

Ovogenetic Activity of the Fetal-Type in the Ovary of the Adult Slow Loris Nycticebus

coucang. Duke, K. L. 7 (2): 150-154(1967).

Chromosome Dimorphism in Primates. Egozcue, J. 7 (3-4): 231-237 (1967).

Food-Motivated Behavior in Prosimians. Ehrlich, A. 8 (1): 66-71 (1968).

Activity Levels in Prosimians. Ehrlich, A. 8(1): 72-76 (1968).

The Cerebral Arteries of Nycticebus coucang coucang. Krishnamurti, A. 8 (2): 159-168

(1968).

Microscopic Anatomy and the Attenuation of Elastic Tissue in the Aortic Wall of Slow Loris

(Nycticebus coucang coucang). Ahmed, M.M. 8 (3-4): 290-300 (1968).

Nerve Endings in the Skin of the Foetal Hand of Slow Loris. Kanagasunthe-ram, R. and

Krishnamurti, A. 10 (4): 263-275 (1969).

Innervation of Oral Tissues in Some Primates. Vij, S. and Kanagasuntheram, R. 11 (4): 289299 (1969). 
Nerve Terminations in the Digital Skin of the Hand in Some Lorisoids. Kanagasuntheram, R.; Krishnamurti, A., and Ahmed, M. 12 (1): $42-55$ (1970).

The Nasal Fossa of Tupaia glis and Nycticebus coucang. Loo, S.K. and Kanagasuntheram, R. 16 (1-2): 74-84 (1971).

Glucose Preferences in the Greater Galago (Galago crassicaudatus) and Slow Loris

(Nycticebus coucang). Fobes, J.L. and Ehrlich, A. 16 (3-4): 306-311 (1971).

A Comparative Histochemical Study of the Mucins of the Nasal Fossa in Four Primates. Loo, S.K.; Kanagasuntheram, R., and Tock, E.P.C. 17 (4): 275-284 (1972).

A Comparative Study of the Nasal Fossa of Four Nonhuman Primates. Loo, S.K. 20 (5-6):

410-422 (1973).

'Folia Primatologica'

Comparative Study of the Histology of the Nasal Fossa in Four Primates. Loo, S.K. 21 (3-4): 290-303 (1974).

The Influence of Selective Logging on Primates and some other Animals in East Kalimantan. Wilson, C. C. and Wilson, W.L. 23 (4): 245-274 (1975).

Die Fazialismuskeln von Perodicticus potto und Nycticebus coucang. Seller, R. 23 (4): 275289 (1975).

Preliminary Study of the Comparative Anatomy of the External Nose of South American Monkeys. Hofer, H.O. 25 (2-3): 193-214 (1976).

Twilight Zeitgebers, Weather, and Activity of Nocturnal Primates. Kavanau, J. L. and Peters, C. R. 26 (1): 67-79 (1976).

Banding Patterns of the Chromosomes of Nycticebus coucang (Boddaert, 1785). Garcia, M.; Miró, R., and Egozcue, J. 29(2): 103-106(1978).

Perodicticus potto

An Apparent Example of Displacement

Behavior in the Prosimian Perodicticus

potto. Cowgill, U.M. 8 (2): 148-149

(1968). Some Observations on the Prosimian

Perodicticus potto. Cowgill, U.M. 11

(1-2): 144-150(1969). Die Fazialismuskeln von Perodicticus potto

und Nycticebus coucang. Seiler, R. 23

(4): 275-289 (1975).

Galaginae

Vertical Clinging and Leaping - a Newly Recognized Category of Locomotor Behaviour of Primates. Napier, J.R. and Walker, A.C. 6 (3-4): 204-219 (1967).

Mother-Infant Relationship in Galagos and the Oral Child-Transport Among Pri-

Systematic Index

249

mates. Sauer, E.G.F. 7 (2): 127-149

(1967). Genetic and Biochemical Studies of Trans-

ferrins and Hemoglobins of Galago.

Nute, P.E.; Buettner-Janusch, V., and Buettner-Janusch, J. 10 (4): 276-

287 (1969). Notes on Ecological Relationships of Four

Species of Lorisids in Rio Muni, West 
Africa. Jones, C. 11 (4): 255-267 (1969). The Chromosomes of the Lesser Bushbaby

(Galago senegalensis) and the Greater

Bushbaby (Galago crassicaudatus).

Egozcue, J. 12 (3): 236-240 (1970). Discrimination of Young in Galagos.

Klopfer, P.H. 13 (2-3): 137-143 (1970). Hematology of Prosimian Primates: Galago,

Lemur and Propithecus. Bergeron, J. A.

and Buettner-Janusch, J. 13 (2-3):

155-165(1970). Notes on the Ecology of Five Lorisiformes

of Rio Muni. Sabater Pi, J. 18 (1-2):

140-151 (1972). Phylogeny of Lemurs, Galagos and Lorises.

Szalay, F.S. and Katz, C.C. 19 (2-3):

88-103 (1973). Patterns of Activity in Three Nocturnal

Prosimian Species, Galago senegalensis

moholi, G. crassicaudatus umbrosus, and

Microcebus murinus murinus, under

Semi-Natural Conditions. Pinto, D.;

Doyle, G.A., and Bearder, S.K. 21

(2): 135-147(1974).

Galago crassicaudatus

The Breeding of Galagos in Captivity and Some Notes on their Behavior. Buett-nert-Janusch, J. 2 (2): 93-110 (1964).

Composition of Milk from Galago crassicaudatus. Pilson, M.E.Q. and Cooper, R.W. 5 (1-2): 88-91 (1967).

Mother-Infant Relationship in Galagos and the Oral Child-Transport Among Primates. Sauer, E.G.F. 7 (2): 127-149 (1967).

Food-Motivated Behavior in Prosimians. Ehrlich, A. 8 (1): 66-71 (1968).

Activity Levels in Prosimians. Ehrlich, A. 8(1): 72-76 (1968).

Genetic and Biochemical Studies of Trans-ferrins and Hemoglobins of Galago. Nute, P.E.;

Buettner-Janusch, V., and Buettner-Janusch, J. 10 (4): 276-287 (1969).

The Chromosomes of the Lesser Bushbaby (Galago senegalensis) and the Greater Bushbaby

(Galago crassicaudatus). Egozcue, J. 12 (3): 236-240 (1970).

Discrimination of Young in Galagos. Klopfer,P.H. 13 (2-3): 137-143 (1970).

Haptoglobins and Acid Phosphatases of Galago. Buettner-Janusch, J. and Wiggins, R.C. 13

(2-3): 166-176(1970).

Social Interactions of Galago crassicaudatus. Roberts, P. 14 (3-4): 171-181 (1971).

Glucose Preferences in the Greater Galago (Galago crassicaudatus) and Slow Loris

(Nyctícebus coucang). Fobes, J. L. and Ehrlich, A. 16 (3-4): 306-311 (1971).

Aufzucht des Halbaffen Galago crassicaudatus E. Geoffroy, 1812 (Lorisiformes: Galagidae)

im Familienverband. Wel-ker, C. 18 (5-6): 379-389 (1972).

Ethologische Bedeutung des Harnwaschens von Galago crassicaudatus E. Geoffroy, 1812

(Lorisiformes: Galagidae). Wel-ker, C. 20 (5-6): 429-452 (1973).

Patterns of Activity in Three Nocturnal Prosimian Species, Galago senegalensis moholi, G. crassicaudatus umbrosus, and Microcebus murinus murinus, under Semi-Natural Conditions. Pinto D.; Doyle, G.A., and Bearder, S.K. 21 (2): 135-147(1974).

On the Denticles of the Sublingua in Galago crassicaudatus E. Geoffroy, 1812 (Primates, Prosimiae, Lorisiformes). Hofer, H.O. 24 (2-3): 188-202 (1975). 
Effects of Testosterone on the Sternal Cutaneous Glands and Genitalia of the Male Greater Galago (Galago crassi-

250

A Topical Guide to 'Folia Primatologica'

caudatus crassicaudatus). Dixon, A.F. 26 (3): 207-213 (1976). Fishing Behaviour in Galago crassicaudatus E. Geoffroy, 1812 (Prosimiae); Lorisi-formes; Galagidae). Welker, C. 26 (4): 284-291 (1976).

G. senegalensis

The Structure of the Allantoic Placenta of the Senegal Bush Baby (Galago senegalensis senegalensis). Butler, H. and Adam, K.R. 2 (1): 22-49 (1964).

Some Notes on the Distribution of Primates in the Sudan. Butler, H. 4 (6): 416-423 (1966). Seasonal Breeding of the Senegal Galago (Galago senegalensis senegalensis) in the Nuba Mountains, Republic of the Sudan. Butler, H. 5 (3): 165-175 (1967).

Mother-Infant Relationship in Galagos and the Oral Child-Transport Among Primates. Sauer, E.G.F. 7 (2): 127-149 (1967).

A Facility for Naturalistic Studies of the Lesser Bushbaby (Galago senegalensis moholi). Doyle, G.A. and Bekker, T. 7 (3-4): 161-168 (1967).

Courtship, Mating and Parturition in the Lesser Bushbaby (Galago senegalensis moholi) under Semi-Natural Conditions. Doyle, G.A.; Pelletier, A., and Bekker, T. 7 (3-4): 169-197 (1967).

Genetic and Biochemical Studies of Trans-ferrins and Hemoglobins of Galago. Nute, P.E.; Buettner-Janusch, V., and Buettner-Janusch, J. 10 (4): 276-287 (1969).

Maternal Behaviour in the Lesser Bushbaby (Galago senegalensis moholi) under SemiNatural Conditions. Doyle, G. A.; Andersson, A., and Bearder, S.K. 11 (3): 215-238 (1969). Nerve Terminations in the Digital Skin of the Hand in Some Lorisoids. Kanagasuntheram, R.; Krishnamurtí, A., and Ahmed, M. 12(1): 42-55 (1970).

The Chromosomes of the Lesser Bushbaby (Galago senegalensis) and the Greater Bushbaby (Galago crassicaudatus). Egozcue, J. 12 (3): 236-240 (1970).

Discrimination of Young in Galagos. Klopfer, P. H. 13 (2-3): 137-143 (1970).

Septic Abortion in the Senegal Bush Baby (Galago senegalensis senegalensis). Butler, H. 13 (2-3): 207-212 (1970).

Reproduction in the Lesser Bushbaby (Galago senegalensis moholi) under Semi-Natural Conditions. Doyle, G.A.; Andersson, A., and Bearder, S.K. 14 (1-2): 15-22 (1971).

The Hemogram of the Colonized Lesser Bushbaby (Galago senegalensis). Hai-nes, D.E.; Holmes, K.R., and Brett, I.J. 14 (1-2): 95-100 (1971).

The Intrinsic Adrenergic and Cholinergic Innervation of the Genitalia of Galago and Tupaia. The Penis. Dail, W.G.; Norvell, J.E., and Haines, D.E. 16 (3-4): 221-230 (1971).

The Chronology of Embryogenesis in the Lesser Galago: a Preliminary Account. Butler, $\mathrm{H}$. 18 (5-6): 368-378 (1972).

Patterns of Activity in Three Nocturnal Prosimian Species, Galago senegalensis moholi, G. crassicaudatus umbrosus, and Microcebus murinus murinus, under Semi-Natural Conditions. Pinto, D.; Doyle, G.A., and Bearder, S.K. 21 (2): 135-147 (1974).

Twilight Zeitgebers, Weather, and Activity of Nocturnal Primates. Kavanau, J.L. and Peters, C.R. 26 (1): 67-79 (1976).

Tarsiiformes 
Tarsius sp.

Untersuchungen an Tarsius. I. Morphologie des Schwanzes nebst ethologischen Bemerkungen. Sprankel, H. 3 (2-3): 153-188 (1965).

Systematic Index

251

Vertical Clinging and Leaping - a Newly Recognized Category of Locomotor Behaviour of Primates. Napier, J.R. and Walker, A.C. 6 (3-4): 204-219 (1967).

Die Bedeutung der Augen für die sagittale Gestaltung des Schädels von Tarsius (Prosimiae, Tarsiiformes). Spatz, W.B. 9(1): 22-40 (1968).

Functional Analysis of the Hip Joint in Tarsius bancanus (Horsfield, 1821) and Tarsius syrichta (Linnaeus, 1758). Grand, T.I. and Lorenz, R. 9 (3^4): 161-181 (1968).

Vergleichend-morphologische und histo-logische Untersuchungen am Integument des Schwanzes von Tarsius syrichta (L., 1758) und Tarsius bancanus (Horsfield, 1821). Kyesel, U. 9 (3-4): 182-215 (1968).

Major Salivary Glands of the Philippine Tarsier. Smith, A.A. 10 (1-2): 113-130 (1969). A Contribution to the Postnatal Behavioral Development of Tarsius bancanus, Horsfield, 1821, Studied in Two Cases. Niemitz, C. 21 (3-4): 250-276 (1974).

The Ectotympanic Bone and Origin of Higher Primates. Hershkovitz, P. 22 (4): 237-242 (1974).

The Influence of Selective Logging on Primates and some other Animals in East Kalimantan. Wilson, C.C. and Wilson, W.L. 23 (4): 245-274 (1975).

The Contrahens Muscle Layer in Tarsius. Day, M. H. and Iliffe, S. R. 24 (4): 241-249 (1975). On the Sublingual Structures of Tarsius (Prosimiae, Tarsiiformes) and Some Platyrrhine Monkeys (Platyrrhina, Si-miae, Primates) with Casual Remarks on the Histology of the Tongue. Hofer, H.O. 27 (4): 297-314 (1977).

The Orbital Mosaic in Prosimians and the Use of Variable Traits in Systematics. Cartmill, M. 30 (2): 89-114 (1978).

Platyrrhina

Vorkommen, Morphologie und Funktion der Sternaldrüse bei den Platyrrhini. Epple, G. und Lorenz, R. 7 (2): 98-126 (1967).

The Chromosomes of Saguinus fuscicollis illigrei (Pucheran, 1845) and Aotus trivirgatus (Humboldt, 1811). Egozcue, J.; Perkins, E.M., and Hagemenas, F. 10(1-2): 154-159(1969). Notes on Tertiary Platyrrhine Monkeys and Description of a New Genus from the Late Miocene of Colombia. Hershkovitz, P. 12(1): 1-37(1970).

Beziehungen zwischen der Neugeborenen-grösse und dem Sexualdimorphismus am Becken bei simischen Primaten. Leutenegger, W. 12 (3): 224-235 (1970).

Cerebral Fissural Patterns in Platyrrhine Monkeys. Hershkovitz, P. 13 (2-3): 213-240 (1970). Sequence of Eruption of Permanent Teeth and Epiphyseal Union in New World Monkeys.

Tappen, N. C. and Severson, A. 15 (3-4): 293-312 (1971).

Le regime alimentaire des Primates de Гîle de Barro-Colorado (Panama). Résultats des analyses quantitatives. Hladik, C. M.; Hladik, A.; Bousset, J.; Valde-bouze, P.; Viroben, G. et Delort-Laval, J. 16 (1-2): 85-122 (1971).

Die Reaktion bei einigen Primaten auf zwei künstliche Süssstoffe und $7 / 8 \mathrm{O}$ dest. Glaser, D. 18 (5-6): 433-443 (1972). 
A New Genus of Late Oligocene Monkey (Cebidae, Platyrrhini) with Notes on Postorbital Closure and Platyrrhine Evolution. Hershkovitz, P. 21 (1): 1-35 (1974).

The Ectotympanic Bone and Origin of Higher Primates. Hershkovitz, P. 22 (4): 237-242 (1974).

The Taste Responses in Primates to the Proteins Thaumatin and Monellin and 252

A Topical Guide to 'Folia Primatologica'

their Phylogenetic Implications. Gla-ser, D.; Hellekant, G.; Brouwer, J.N., and Wel, H. van der. 29 (1): 56-63 (1978). The Orbital Mosaic in Prosimians and the Use of Variable Traits in Systematics. Cartmill, M. 30 (2): 89-114 (1978).

Callitrichidae

Vergleichende Untersuchungen über Sexual-und Sozialverhalten der Krallenaffen

(Hapalidae). Epple, G. 7 (1): 37-65 (1967).

Vorkommen, Morphologie und Funktion der Sternaldrüse bei den Platyrrhini. Epple, G. und Lorenz, R. 7 (2): 98-126 (1967).

Comparative Studies on Vocalization in Marmoset Monkeys (Hapalidae). Epple, G. 8(1): 140(1968).

Chromosomal Evolution in Marmosets, Tamarins, and Pinches. Egozcue, J.; Perkins, E.M., and Hagemenas, F. 9 (2): 81-94(1968).

Geschmacksschwellenwerte bei Callithrici-dae (Platyrrhina). Glaser, D. 9 (3-4): 246257(1968).

Maintenance, Breeding, and Development of Marmoset Monkeys (Callithricidae) in Captivity. Epple, G. 12 (1): 56-76 (1970).

Geschmacksschwellenwerte von verschie-denen Zuckerarten bei Callithricidae (Platyrrhina). Glaser, D. 13 (1): 40-47 (1970).

Chromosomes of Callithricidae with Special Reference to an XX/'XO' Sex Chromosome System in Goeldi's Marmoset (Callimico goeldii Thomas, 1904). Hsu, T.C. and Hampton, S.H. 13 (2-3): 183-195 (1970).

Comments on the Taxonomy of Brazilian Marmosets (Callithrix, Callitrichidae).

Hershkovitz, P. 24 (2-3): 137-172 (1975).

Erythroblastosis Models. II. Materno-Fetal Incompatibility in Chimpanzee. Wiener, A.S.; Socha, W.W., and Moor-Jankowski, J. 27 (1): 68-74 (1977).

On the Sublingual Structures of Tarsius (Prosimiae, Tarsiiformes) and Some Platyrrhine Monkeys (Platyrrhina, Si-miae, Primates) with Casual Remarks on the Histology of the Tongue. Hofer, H.O. 27 (4): 297-314 (1977).

Callithrix sp.

Congenital Abnormalities of the Urinary Tract in Primates. Hill, W.C. Osman 2(2): 111-118 (1964).

Maintenance, Breeding, and Development of Marmoset Monkeys (Callithricidae) in Captivity. Epple, G. 12 (1): 56-76 (1970).

Quantitative Studies on Scent Marking in the Marmoset (Callithrix jacchus). Epple, G. 13 (1): 48-62 (1970).

Gonadotrophin Concentrations in the Placentae of Man, the Rhesus Monkey and the Marmoset. Hobson, B. M. 18 (1-2): 35-40(1972). 
Beobachtungen zur Geburt beim Weiss-büscheläffchen (Callithrix jacchus Erx-leben, 1777). Rothe, H. 19 (4): 257-285 (1973).

New Data on the Taxonomy of the Brazilian Marmosets of the Genus Callithrix Erxleben, 1777. Coimbra-Filho, A.F. and Mittermeier, R. A. 20 (4): 241-264 (1973).

Comments on the Taxonomy of Brazilian Marmosets (Callithrix, Callitrichidae).

Hershkovitz, P. 24 (2-3): 137-172 (1975).

On the Sublingual Structures of Tarsius (Prosimiae, Tarsiiformes) and Some Platyrrhine Monkeys (Platyrrhina, Si-miae, Primates) with Casual Remarks on the Histology of the Tongue. Hofer, H.O. 27 (4): 297-314 (1977).

Systematic Index

253

Urinary Excretion of Biologically Active Chorionic Gonadotrophin by the Pregnant Marmoset (Callithrix jacchus jacchus). Hobson, B. M.; Hearn, J.P.; Lunn, S.F., and Flockhart, J.H. 28 (4): 251-258 (1977).

Composition of the Milk of the Common Marmoset (Callithrix jacchus) and Milk Substitutes Used in Hand-rearing Programmes, with Special Reference to Fatty Acids. Turton, J. A.; Ford, D. J.; Bleby, J.; Hall, B.M., and Whiting, R. 29(1): 64-79 (1978).

Cebuella pygmaea

Body Temperature and Metabolism in the Pigmy Marmoset. Morrison, P. and Middleton, E. H. 6 (1-2): 70-82 (1967).

Haltung und Brutbiologie von Cebuella. Christen, A. 8 (1): 41-49 (1968).

The Somatic and Meiotic Chromosomes of Cebuella pygmaea (Spix 1823) with Special Reference to the Behavior of the Sex Chromosomes During Spermato-genesis. Egozcue, J.; Chiarelli, B., and Sarti-Chiarelli, M. 8 (1): 50-57 (1968).

Geschmacksschwellenwerte bei Callithrici-dae (Platyrrhina). Glaser, D. 9 (3-4): 246-257 (1968).

Geschmacksschwellenwerte von verschie-denen Zuckerarten bei Callithricidae (Platyrrhina). Glaser, D. 13 (1): 40-47 (1970).

On the Sublingual Structures of Tarsius (Prosimiae, Tarsiiformes) and Some Platyrrhine Monkeys (Platyrrhina, Si-miae, Primates) with Casual Remarks on the Histology of the Tongue. Hofer, H.O. 27 (4): 297-314 (1977).

Saguinus sp. Observations on a Successful Breeding

Colony of the Marmoset, Oedipomidas oedipus. Hampton, J.K., jr.; Hampton, S.H., and Landwehr, B.T. 4 (4): 265-287 (1966).

Taxonomic Notes on Tamarins, Genus Saguinus (Callithricidae, Primates), with Descriptions of Four New Forms. Hershkovitz, P. 4 (5): 381-395 (1966).

Haltung und Brutbiologie von Cebuella. Christen, A. 8 (1): 41-49 (1968).

Chromosome Study of a Marmoset Hybrid. Low, R. J. and Benirschke, K. 8 (3-4): 180-191

(1968).

Observations of the Tamarin Saguinus midas. Thorington, R.W., jr. 9 (1): $95-98$ (1968).

Geschmacksschwellenwerte bei Callithricidae (Platyrrhina). Glaser, D. 9 (3-4): 246-257

(1968).

The Chromosomes of Saguinus fuscicollis illigrei (Pucheran, 1845) and Aotus tri-virgatus (Humboldt, 1811). Egozcue, J.; Perkins, E.M., and Hagemenas, F. 10(1-2): 154-159(1969). 
Maintenance, Breeding, and Development of Marmoset Monkeys (Callithricidae) in Captivity. Epple, G. 12 (1): 56-76 (1970).

Geschmacksschwellenwerte von verschie-denen Zuckerarten bei Callithricidae (Platyrrhina). Glaser, D. 13 (1): 40-47 (1970).

Sequence of Eruption of Permanent Teeth and Epiphyseal Union in New World Monkeys. Tappen, N. C. and Severson, A. 15 (3-4): 293-312 (1971).

Le regime alimentaire des Primates de Гîle de Barro-Colorado (Panama). Résultats des analyses quantitatives. Hladik, CM.; Hladik, A.; Bousset, J.; Valde-bouze, P.; Viroben, G. et Delort-Laval, J. 16 (1-2): 85-122 (1971).

A Case of Syndactyly in the White-Lipped Tamarin Saguinus nigricollis. Hether-ington, CM.; Cooper, J.E., and Dawson, P. 24 (1): 24-28 (1975).

Parental Behavior in Saguinus fuscicollis

254

A Topical Guide to 'Folia Primatologica'

ssp. (Callithricidae). Epple, G. 24 (2-3): 221-238 (1975).

Vocalizations and their Behavioral Contexts in the Tamarin Saguinus fuscicollis. Moody, M.I. and Menzel, E.W., jr. 25 (2-3): 73-94 (1976).

Verhaltens- und elektrophysiologische Ex-perimente über den Geschmackssinn bei Saguinus midas tamarin (Callitrichidae). Glaser, D. und Hellekant, G. 28 (1): 43-51 (1977).

The Banded Karyotype of Saguinus midas tamarin Link, 1795 (Callitrichidae, Primates). Schmid, W. and Glaser, D. 28 (2): 154-158(1977).

The Social Behavior of a Marmoset (Saguinus fuscicollis) Group. III. Spatial Analysis of Social Structure. Vogt, J. L. 29 (4): 250-267 (1978).

Leontopithecus rosalia

An Early Twin Blastocyst of the Golden Lion Marmoset, Leontocebus rosalia L. Benirschke, K. and Layton, W. 10 (1-2): 131-138 (1969).

Maintenance, Breeding, and Development of Marmoset Monkeys (Callithricidae) in Captivity. Epple, G. 12 (1): 56-76 (1970).

Food Sharing among Captive Leontopithecus rosalia. Brown, K. and Mack, D.S. 29 (4): 268290 (1978).

Callimico goeldii

Beitrag zur Morphologie und körperlichen Jugendentwicklung des Springtamarin Callimico goeldii (Thomas, 1904). Lo-renz, R. und Heinemann, H. 6 (1-2): 1-27 (1967).

Vergleichende Untersuchungen über Sexual-und Sozialverhalten der Krallenaffen

(Hapalidae). Epple, G. 7 (1): 37-65 (1967).

Vorkommen, Morphologie und Funktion der Sternaldrüse bei den Platyrrhini. Epple, G. und Lorenz, R. 7 (2): 98-126 (1967).

Comparative Studies on Vocalization in Marmoset Monkeys (Hapalidae). Epple, G. 8(1): 140(1968).

Chromosomal Evolution in Marmosets, Tamarins and Pinches. Egozcue, J.; Perkins, E.M., and Hagemenas, F. 9 (2): 81-94 (1968).

Chromosomes of Callithricidae with Special Reference to an XX/'XO' Sex Chromosome System in Goeldi's Marmoset \{Callimico goeldii Thomas, 1904). Hsu, T.C. and Hampton, S.H. 13 (2-3): 183-195 (1970). 
Goeldi's Monkey Callimico goeldii Thomas 1904 Preying on Snakes. Lorenz, R. 15 (1-2): 133-142(1971).

Zur Morphometrie und Histologie des Auges des Springtamarins \{Callimico goeldii Thomas, 1904, Caliimiconidae, Primates). Castenholz, A.; Lorenz, R. und Castenholz, E. 29 (3): 161177 (1978).

Cebidae

Vorkommen, Morphologie und Funktion der Sternaldrüse bei den Platyrrhini. Epple, G. und Lorenz, R. 7 (2): 98-126 (1967).

Position of the Centromere in the Marked Acrocentric Chromosomes of Primates. Egozcue, J. 7 (3-4): 238-242 (1967).

On the Recessus Mesocoelicus in some Primates. Hofer, H.O. 15 ( $\left.3^{\wedge} 1\right)$ : 249-263 (1971).

Le regime alimentaire des Primates de 1'île de Barro-Colorado (Panama). Résultats des

analyses quantitatives. Hladik, C. M.; Hladik, A.; Bousset, J.; Valde-bouze, P.; Viroben, G. et Delort-Laval, J. 16 (1-2): 85-122 (1971).

Systematic Index

255

Cytogenetics and Taxonomy of some South Bolovian Monkeys. Cambefort, Y. and Moro, F. 29 (4): 307-314 (1978).

Aotinae

Aotus trivirgatus

Food-Motivated Behavior in Prosimians. Ehrlich, A. 8 (1): 66-71 (1968)

The Chromosomes of Saguinus fuscicollis illigrei (Pucheran, 1845) and Aotus trivirgatus

(Humboldt, 1811). Egozcue, J.; Perkins, E.M., and Hagemenas, F. 10(1-2): 154-159(1969).

The Chromosomes of Aotus trivirgatus Humboldt, 1812. Brumback, R.A.; Staton, R.D.;

Benjamin, S.A., and Lang, CM. 15 (3-4): 264-273 (1971).

A Note on the Chromosomes of Aotus tri-virgatus Humboldt, 1812. Egozcue, J. 15 (3-4):

274-276 (1971).

Evolution of the Marked Chromosomes of Primates. Experimental Evidence for Pericentric Inversion. Egozcue, J. 16 (3-4): 276-281 (1971).

Serotaxonomy of Aotus. A Preliminary Study. Brumback, R.A. and Willen-borg, D.O. 20(23): 106-111 (1973).

Beleuchtungsabhängiges Aktivitätsopti-mum bei Nachtaffen (Aotus trivirgatus). Erkert, H.G. 25 (2-3): 186-192 (1976).

Preliminary Study of the Comparative Anatomy of the External Nose of South American

Monkeys. Hofer, H.O. 25 (2-3): 193-214(1976)

Twilight Zeitgebers, Weather, and Activity of Nocturnal Primates. Kavanau, J. L. and Peters, C.R. 26 (1): 67-79 (1976).

Genus Aotus Q- and G-Band Karyotypes in Natural Hybrids. Yunis, E.; Torres De Caballero, O.M., and Ramirez, C. 27 (3): 165-177 (1977).

Brightness Preference in Nocturnal and Diurnal South American Monkeys. Jakobs, G.H. 28

(3): 231-240 (1977).

Home Range, Activity Pattern, and Agonistic Encounters of a Group of Night Monkeys

(Aotus trivirgatus) in Peru. Wright, P.C. 29 (1): 43-55 (1978).

Cytogenetics and Taxonomy of some South Bolivian Monkeys. Cambefort, Y. and Moro, F. 29 (4): 307-314 (1978). 
Callicebus sp.

The Chromosomes of Some Platyrrhini (Callicebus, A teles and Saimiri). Egozcue, J.;

Perkins, E.M.; Hagemenas, F., and Ford, D.M. 11 (1-2): 17-27 (1969).

On the Organon Sublinguale in Callicebus (Primates, Platyrrhini). Hofer, H. 11 (4): 268-288

(1969).

Comparative Studies of Social Behavior in Callicebus and Saimiri: Behavior of Male-Femal Pairs. Mason, W.A. 22 (1): 1-8 (1974).

Comparative Studies of Social Behavior in Callicebus and Saimiri: Strength and Specificity of Attraction between Male-Female Cagemates. Mason, W.A. 23 (1-2): 113-123(1975).

Chromosomes of the Tan-Handed Titi (Callicebus torquatus, Hoffmannsegg, 1807).

Benirschke, K. and Bogart, M.H. 25(1): 25-34 (1976).

A Comparative Study on the Microscopic Anatomy of the Sublingua oîTupaiaglis

(Tupaiiformes). Hofer, H. and Mernel, W. 26 (3): 229-243 (1976).

Food Transfer by Wild Titi Monkeys (Callicebus torquatus torquatus). Starin, E.D. 30 (2):

145-151 (1978).

Pitheciinae

The Somatic Chromosome Complement and the Idiogram of Pithecia pithecia pithecia

(Linnaeus, 1766). De Boer, L. E.M. 23 (1-2): 149-157 (1975).

256

A Topical Guide to 'Folia Primatologica'

Alouattinae

Beobachtungen an dem sogenannten «Su-pracommissuralen Organ» (Fuse) und am Recessus mesocoelicus der Primaten. Hofer, H. 5 (3): 190-200 (1967).

Congenital Renal Malformations in Monkeys. Maruffo, C.A. and Cramer, D. L. 5 (4): $305-$

311 (1967).

Chromosome Dimorphism in Primates. Egozcue, J. 7 (3-4): 231-237 (1967).

A Comparative Study of the Activity Patterns and Behavior of Alouatta villosa and Ateles geoffroyi. Richard, A. 12 (4): 241-263(1970).

Ossa suprasternalia der Primaten und die Spezialanpassungen des Manubrium sterni bei den

Brüllaffen (Alouatta). Klima, M. 17 (5-6): 421^133 (1972).

Preliminary Study of the Comparative Anatomy of the External Nose of South American

Monkeys. Hofer, H.O. 25 (2-3): 193-214(1976).

Cranial and Dental Anomalies in Three Species of Platyrrhine Monkeys from Nicaragua.

Smith, J. D; Genoways, H. H., and Jones, J.K., jr. 28 (1): 1-42 (1977).

Non-Metric Features in the Ulna of Aegyptopithecus, Alouatta, Ateles, and Lagothrix.

Schòn, Ybarra, M.A. and Conroy, G.C. 29 (3): 178-195 (1978).

Alouatta palliata

On the Daily Behaviour and Spacing of

Howling Monkey Groups. Chivers, D.

J. 10 (1-2): 48-102 (1969). Interactions between Adult Female and

Infant Howling Monkeys (Alouatta

palliata). Baldwin, J. D and Baldwin,

J.I. 20(1): 27-71 (1973). Urine-Rubbing Behavior in the Mantled

Howler Monkey Alouatta palliata.

Milton, K. 23 (1-2): 105-112 (1975). Postural and Locomotor Behavior of 
Alouatta palliata on Various Substrates.

Mendel, F. 26 (1): 36-53 (1976). Vocalizations of Howler Monkeys (Alouatta

palliata) in Southwestern Panama.

Baldwin, J.D. and Baldwin, J.I 26

(2): 81-108 (1976). Drinking from Arboreal Water Sources by

Mantled Howling Monkeys \{Alouatta

palliata Gray). Glander, K.E. 29 (3):

206-217 (1978).

A.seniculus

The Anatomy of the Resonating Mechanism in Howling Monkeys. Schön, M.A. 15 (1-2):

117-132(1971).

The Population Structure of Red Howler Monkeys (Alouatta seniculus) in Trinidad and Venezuela. Neville, M.K. 17 (1-2): 56-86(1972).

Social Relations within Troops of Red Howler Monkeys (Alouatta seniculus). Neville, M.K. 18 (1-2): 47-77 (1972).

Chromosomal Variations in the Primate Alouatta seniculus seniculus. Yunis, E. J.; Torres De

Caballero, O.M.; Ramírez, C, and Ramírez, Z.E. 25 (2-3): 215-224 (1976).

Cebinae Cebus sp.

Activity Patterns in a Cebus Monkey Group.

Bernstein, I. S. 3 (2-3): 211-224 (1965). The Chromosome Complement of Cebus

albifrons (Erxleben, 1777). Egozcue, J.

and Vilarasau De Egozcue. M. 5 (4):

285-294 (1967). Chromosome Dimorphism in Primates.

Egozcue, J. 7 (3-4): 231-237 (1967). Sequence of Eruption of Permanent Teeth

and Epiphyseal Union in New World

Monkeys. Tappen, N. C. and Severson,

A. 15 (3-4): 293-312 (1971).

Systematic Index

257

Preliminary Observations of Cebus nigri-vittatus (Primates: Cebidae) on the Venezuelan Llanos. Oppenheimer, J. R. and Oppenheimer, E. C. 19 (6): 409^136 1973).

Hematological Development of the Cebus Monkey (Cebus albifrons and apella). Samonds, K.W.; Ausman, L.M., and Hegsted, D.M. 22 (1): $72-79$ (1974).

Banding Patterns of the Chromosomes of Cebus albifrons. Comparative Study with Cebus apella. García, M.; Frei-tag, L.; Miró, R., and Egozcue, J. 25 (4): 313-319 (1976).

Genus Cebus Q- and G-Band Karyotypes and Natural Hybrids. Torres De Ca-ballero, O.M.;

Ramirez, C, and Yunis, E. 26 (4): 310-321 (1976).

Cranial and Dental Anomalies in Three Species of Platyrrhine Monkeys from Nicaragua.

Smith, J.D.; Genoways, H. H., and Jones, J.K., jr. 28 (1): 1-42 (1977).

Banding Patterns of the Chromosomes of Cebus apella: Unstable Chromosomes and

Pericentric Inversion. García, M.; Miró, R.; Freitag, L., and Egozcue, J. 29(3): 196-

205(1978).

Cytogenetics and Taxanomy of some South Bolivian Monkeys. Cambefort, Y and Moro, F. 29 (4): 307-314 (1978).

Saimiri sciureus 
Studies on Social and Sexual Behavior of the Squirrel Monkey (Saimiri sciureus). Ploog, D. W.; Blitz, J., and Ploog, F. 1 (1): 29-66 (1963).

Pregnancy and Delivery Behavior in the Squirrel Monkey (Saimiri sciureus) and Other Primates. Bowden, D.; Winter, P., and Ploog, D. 5 (1-2): 1-42 (1967).

Congenital Renal Malformations in Monkeys. Maruffo, C.A. and Cramer, D. L. 5 (4): 305-

311 (1967).

Vaginal Comification Cycles in the Squirrel

Monkey (Saimiri sciurea). Rosenblum, L.A.; Nathan, T.; Nelson, J., and Kaufmann, I.C. 6 (12): 83-91 (1967).

Das sogenannte Urinmarkieren von Toten-kopfaffen (Saimiri sciureus) in Abhän-gigkeit von umweltbedingten und emo-tionalen Faktoren. Castell, R. und Maurus, M. 6 (3-4): 170-176 (1967).

Untersuchungen über die Einflüsse der sozialen Organisation der Totєnkopf-äffchen (Saimiri sciureus) auf das in-strumentelle Lernen bzw. die selbst-gewählte Reihenfolge in den Versuchen. Jarosch, E. 9 (2): 135-153 (1968).

The Social Behavior of Adult Male Squirrel Monkeys (Saimiri sciureus) in a Semi-natural Environment. Baldwin, J.D.

9 (3-4): 281-314 (1968).

The Variability of Peep and Twit Calls in Captive Squirrel Monkeys (Saimiri sciureus).

Winter, P. 10 (3): 204-215 (1969).

Dialects in Squirrel Monkeys: Vocalization of the Roman Arch Type. Winter, P.

10 (3): 216-229 (1969).

The Accessory Optic System and Other Optic Fibres of the Squirrel Monkey. Tigges, J. and Tigges, M. 10 (4): 245-262 (1969).

The Chromosomes of Some Platyrrhini (Callicebus, A teles and Saimiri). Egozcue, J.;

Perkins, E. M.; Hagemenas, F., and Ford,D.M. 11 (1-2): 17-27(1969).

The Ontogeny of social Behavior of Squirrel Monkeys (Saimiri sciureus) in a Semi-natural Environment. Baldwin, J.D.

11 (1-2): 35-79 (1969).

Ontogeny of the Gut Pattern in Saimiri. Hill, W.C.O. 11 (3): 166-174 (1969).

Communication during Initial Contact: A Comparison of Squirrel and Rhesus Monkeys.

Castell, R. 11 (3): 206-214 (1969).

Haematological Observations on the Squirrel Monkey. Capel-Edwards, K. and Hall, D.E. 12

(2): 142-160 (1970).

Vaginal Cytology and Reproduction in the

258 A Topical Guide to 'Folia Primatologica'

Squirrel Monkey (Saimiri sciureus). Hutchinson, T.C. 12 (3): 212-223 (1970).

The Social Organization of a Semifree. Ranging Troop of Squirrel Monkeys (Saimiri sciureus). Baldwin, J.D. 14 (1-2): 23-50 (1971).

Rank Order in a Captive Female Squirrel Monkey Colony. Castell, R. and Heynrich, B. 14 (34): 182-189 (1971).

Sequence of Eruption of Permanent Teeth and Epiphyseal Union in New World Monkeys.

Tappen, N. C. and Severson, A. 15 (3-4): 293-312 (1971).

Vergleichende Untersuchungen über den Geschmackssinn der Primaten. Glaser, D. 17 (4): 267-274 (1972).

Composition of Squirrel Monkey Milk. Buss, D.H. and Copper, R.W. 17 (4): 285-291 (1972). 
Study of Spontaneous Behavior in Squirrel Monkey Groups: Observation Techniques, Recording Devices, Numerical Evaluation and Reliability Test. Hopf, S. 17 (5-6): 363-388 (1972).

Effect of Deafening on the Vocal Behavior of the Squirrel Monkey (Saimiri sciureus).

Talmage-Riggs, G.; Winter, P.; Ploog, D., and Mayer, W. 17 (5-6): 404-420 (1972).

The Ecology and Behavior of Squirrel Monkeys (Saimiri oerstedi) in a Natural Forest in Western Panama. Baldwin, J. D. and Baldwin, J.I. 18 (3-4): 161-184 (1972).

Dominance Hierarchy in Squirrel Monkeys (Saimiri sciureus). Role of the Gonads and Androgen on Genital Display and Feeding Order. Green, R. ; Whalen, R. E.; Rutley, B., and Battie, C. 18 (3-4): 185-195 (1972).

Homosexual Behavior and Dominance Hierarchy in a Group of Captive Female Squirrel Monkeys (Saimiri sciureus). Talmage-Riggs, G. and Anschel, S. 19(1): 61-72 (1973).

Notes on Reproduction in Captive Squirrel

Monkeys (Saimirisciureus). Lorenz, R.; Anderson, CO., and Mason, W.A. 19 (4): 286-292 (1973).

Evaluation of the Water Incentive Method of Social Dominance Measurement in Primates.

Clark, D.L. and Dillon, J. E. 19 (4): 293-311 (1973).

Social Preference of the Squirrel Monkey (Saimiri sciureus). Candland, D.K; Tyrrell, D.S.; Wagner, D.S., and Wagner, N.M. 19 (6): 437-449 (1973).

Social Structure of the Squirrel Monkey (Saimiri sciureus, IquitosJ: Relationships among

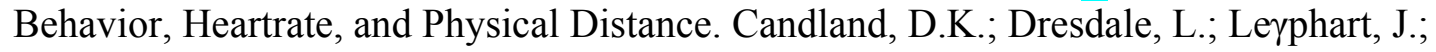
Bryan, D.; Johnson, C, and Nazar, B. 20 (2-3): 211-240(1973).

An Analysis of Subgroup Structure and Process in a Captive Squirrel Monkey (Saimiri sciureus) Colony. Fairbanks, L. 21 (3-4): 209-224 (1974).

The Behavioral Repertoire of the Squirrel Monkey (Saimiri). Hopf, S.; Hart-mann-Wiesner, E.; Kühlmorgen, B., and Mayer, S. 21 (3-4): 225-249 (1974).

Comparative Studies of Social Behavior in Callicebus and Saimiri: Behavior of Male-Female Pairs. Mason, W.A. 22 (1): 1-8 (1974).

Comparative Studies of Social Behavior in Callicebus and Saimiri: Strength and Specificity of Attraction between Male-Female Cagemates. Mason, W.A. 23 (1-2): 113-123 (1975). An Approach to the Interpretation of the Communicative Meaning of Visual Signals in Agonistic Behavior of Squirrel Monkeys. Maurus, M.; Kühlmorgen, B.; Hartmann-Wiesner, E., and Pru-scha, H. 23 (3): 208-226 (1975).

Added Heterochromatin Segments in Chromosomes of Squirrel Monkeys (Saimiri sciureus). Ma, N.S. F. and Jones, T.C. 24 (4): 282-292 (1975).

Hematological Development of the Infant Squirrel Monkey (Saimiri sciureus).

Systematic Index

259

Ausmann, L.M.; Gallina, D.L.; Hayes, K. C, and Hegsted, D. M. 26 (4): 292-300 (1976). The Number of Umbilical Vessels in the Squirrel Monkey (Saimiri sciureus). Baker, C. A. and Hendrickx, A.G. 27 (3): 230-233 (1977).

Social Organization of Captive Monandrous Squirrel Monkey Groups (Saimiri sciureus). Anschel, S. and Talmage-Riggs, G. 28 (3): 203-215 (1977).

Brightness Preference in Nocturnal and Diurnal South American Monkeys. Jacobs, G.H. 28 (3): 231-240 (1977). 
Facial Expressions in Captive Squirrel Monkeys (Saimirisciureus).Marriott, B.M. and Salzen, E.A. 29 (1): 1-18 (1978).

Annual Reproductive Strategy of the Squirrel Monkey (Saimiri sciureus). Coe, C. L. and Rosenblum, L.A. 29 (1): 19-42 (1978).

Cytogenetics and Taxonomy of some South Bolivian Monkeys. Cambefort, Y. and Moro, F. 29 (4): 307-314 (1978).

Social Organization and Social Behavior in Two Subspecies of Squirrel Monkeys (Saimiri sciureus). Mendoza, S.P.; Lowe, E., and Levine, S. 30 (2): 126-144 (1978).

Atelinae

Blood Groups of Apes and Monkeys. VI. Further Studies on the Human Blood Group Factors A,B,H, and Le in Monkeys. Wiener, A.S.; Moor-Jankowski, J., and Gordon, E.B. 4 (2): 81102 (1966).

The Chromosomes of Some Platyrrhini (Callicebus, A teles and Saimiri). Egoz-cue, J.;

Perkins, E. M.; Hagemenas, F., and Ford, D.M. 11 (1-2) :17-27(1969).

The Chromosomes of Humboldt's Woolly Monkey (Lagothríx lagotricha, Hum-boldt, 1812). Egozcue, J. and Perkins,

E.M. 12(1): 77-80 (1970).

A Comparative Study of the Activity Patterns and Behavior of Alouatta villosa and Ateles geoffroyi. Richard, A. 12 (4): 241-263 (1970).

Observations on Copulation and Seasonal Reproduction of Two Species of Spider Monkeys, Ateles belzebuth and A. geoffroyi. Klein, L.L. 15 (3^): 233-248 (1971).

The Contrasting Morphology Found in the Wrist Joints of Semibrachiating Monkeys and Brachiating Apes. Lewis, O. J. 16 ( $\left.3^{\wedge} 1\right): 248-256$ (1971).

Dentition of Brachyteles arachnoides with Reference to Alouattine and Ateline Affinities. Zyngeser, M.R. 20 (5-6): 351-390 (1973).

An Analysis of Adult Social Spacing Tendencies and Related Social Interactions in a Colony of Spider Monkeys (Ateles geoffroyi) at the San Francisco Zoo. Rondinelli, R. and Klein, L.L. 25 (2-3): 122-142(1976).

Cranial and Dental Anomalies in Three Species of Platyrrhine Monkeys from Nicaragua.

Smith, J.D.; Genoways, H. H., and Jones, J.K., jr. 28 (1): 1-42 (1977).

Neue Beobachtungen und Überlegungen zur Pathologie des Primatenschädels. Ein Beitrag zur 'Gundu'-Frage. Schultz, M. und Starck, D. 28 (2): 81-108 (1977).

Non-Metric Features in the Ulna of Aegyptopithecus, Alouatta, Ateles, and Lagothrix. Schön Ybarra, M.A. and Conroy, G.C. 29 (3): 178-195 (1978).

Locomotion and Posture in Ateles geoffroyi and Ateles paniscus. Mittermeier, R. A. 30(3): 161-193(1978).

Catarrhina

Marked Chromosome in Catarrhine Monkeys. Chiarelli, B. 4 (1): 74-80 (1966).

260 A Topical Guide to 'Folia Primatologica'

Intertaxa Interactions in a Malayan Primate Community. Bernstein, I.S. 7 (3-4): 198-207 (1967).

Studies on Folate and Vitamin B12 Metabolism in Primates. I. Blood and Bone Marrow Morphology, Folate and Vitamin B12 Levels. Huser, H.-J. and Beard, M.E.J. 10 (3): 172-180 (1969).

Beziehungen zwischen der Neugeborenen-grösse und dem Sexualdimorphismus am Becken bei simischen Primaten. Leu-tenegger, W. 12 (3): 224-235 (1970). 
Studies on Folate and Vitamin B12 Metabolism in Primates. II. Vitamin B12 Binding Proteins. Beard, M.E.J. and Huser, H.-J. 12 (4): 305-312 (1970).

Luteinizing Hormone Levels in Nonhuman Primates. Blakley, G.A. 13 (4): 298-305 (1970). Intrarenal Arterial Patterns in Nunhuman Primates. Stinson, J. M. 14 (1-2): $70-79$ (1971). Hydronephrosis of Pregnancy: a Naturally Occurring Disorder in Non-Human Primates Closely Resembling that in Man. Roberts, J.A. and Wolf, R.H. 15(1-2): 143-147(1971). Rumpfskelettlänge, Allometrien und Kör-perproportionen bei catarrhinen Primaten. Biegert, J. und Maurer, R. 17 (1-2): 142-156(1972).

On the Corpus adiposum buccae (Bichat) in Pan troglodytes. Hofer, H.O. 17 (5-6): 434-441 (1972).

Osteometric Shape Relationships in the Wrist Joint of Some Anthropoids. Corruccini, R. S.; Ciochon, R. L., and McHenry, H. M. 24(4): 250-274(1975).

Erythroblastosis Models. II. Materno-Fetal Incompatibility in Chimpanzee. Wiener, A.S.; Socha, W.W., and Moor-Jankowski, J. 27 (1): 68-74 (1977).

New Data and a Discussion of Infant Killing in Old World Monkeys and Apes. Angst, W. and Thommen, D. 27 (3): 198-229 (1977).

Competition for Meat between Chimpan-

zees and Baboons of the Gombe National Park. Morris, K. and Goo-dall, J. 28 (2): 109-121 (1977).

Chimpanzee Simian-Type Blood Groups: Reproducibility of Formerly Described Antisera and Demonstration of New Blood Groups Oc and Pcla. Moor-Jan-kowski, J.; Socha, W. W.; Wiener, A. S., and Plonski, H. 28 (3): 216-230 (1977).

The Taste Responses in Primates to the Proteins Thaumatin and Monellin and their Phylogenetic Implications. Glaser, D.; Hellekant, G.; Brouwer, J.N., and Wel, H. van der. 29 (1): 56-63 (1978).

Genetic Variation of Aldehyde Dehydro-genase in Primates. Friedrichson, U.; Ritter, H., and Schmitt, J. 29 (2): 95-97 (1978).

Cercopithecidae

Les chances primatologiques de $\Gamma$ Est-Africain. Bone, E.L. 2 (1): 1-21 (1964).

Marked Chromosome in Catarrhine Monkeys. Chiarelli, B. 4 (1): 74-80 (1966).

Some Notes on the Distribution of Primates in the sudan. Butler, H. 4 (6): 416-423 (1966).

Die Mm. adductores femoris der niederen Altweltaffen (Cercopithecidae). Uhl-mann, K. 6 (1-2): 131-152 (1967).

Intertaxa Interactions in a Malayan Primate Community. Bernstein, I.S. 7 (3-4): 198207(1967).

Red Cell and Serum Proteins of Cercocebus, Presbytis, Colobus and Certain Other Species. Barnicot, N.A. and Hewett-Emmett, D. 17 (5-6): $442-457$ (1972).

Evolution of the Marked Chromosomes of Primates: Experimental Evidence for Centric Fusion. Egozcue, J. 21 (2): 148-151 (1974).

The Influence of Selective Logging on Primates and some other Animals in East Systematic Index

261

Kalimantan. Wilson, C.C. and Wilson, W.L. 23 (4): 245-274 (1975). Comparative Study of the Banding Patterns of the Chromosomes of Cercopithecidae. 
I. Subfamily Papinae: Macaca fascicu-

laris and Papio sphinx. Rubio-Goday,

A.; Caballín, M.R.; Caldés, M.G.,

and Egozcue, J. 26 (4): 306-309 (1976). Differential Habitat Utilization of Four

Cercopithecidae in a Kenyan Forest.

Moreno-Black, G. and Maples, W.R.

27 (2): 85-107 (1977).

Cercopithecinae

Etude électroencéphalographique de deux cynomorphes de ГOuest Africain. Bert, J. and

Collomb, H. 1 (3-4): 137-149 (1963).

Blood Groups of Apes and Monkeys. VI. Further Studies on the Human Blood Group Factors

A, B,H and Le in Monkeys. Wiener, A.S.; Moor-Jankowski, J., and Gordon, E.B. 4 (2): 81102 (1966).

Primate Behavioral Research in the USSR. The Sukhumi Medico-Biological Station Bowden, D. 4 (5): 346-360 (1966).

The Mycoflora of the Subhuman Primates. III. The Flora of the Skin of the Baboon, Vervet, and Gelada in Captivity. Al-Doory, Y. 7 (3-4): 292-298 (1967).

Zur Variabilität des Hautleistensystems der Meerkatzen (Cercopithecus) und des

Husarenaffen (Erythrocebus patas). Brehme, H. 9 (1): 41-67 (1968).

Studies on Folate and Vitamin B12 Metabolism in Primates. I. Blood and Bone Morphology,

Folate and Vitamin B12 Levels. Huser, H.-J. and Beard, M.E. J. 10(3): 172-180(1969).

Correlates of Ecology and Social Organization Among African Cercopithecines. Struhsaker, T.T. 11 (1-2): 80-118 (1969).

L'électroencéphalogramme du sommeil

chez les Cercopithecinae: Erythrocebus patas et Cercopithecus aethiops sabaeus. Bert,

J.etPEGRAM, V. 11 (1-2): 151-159 (1969).

Studies on Folate and Vitamin B12 Metabolism in Primates. II. Vitamin B12 Binding

Proteins. Beard, M.E.J. and Huser, H.-J. 12 (4): 305-312 (1970).

Transferrins of Cercopithecinae. Coppen-haver, D. and Buettner-Janusch, J. 13(1): 23-34

(1970).

Luteinizing Hormone Levels in Nonhuman Primates. Blakley, G.A. 13 (4): 298-305 (1970).

Intrarenal Arterial Patterns in Nonhuman Primates. Stinson, J. M. 14 (1-2): $70-79$ (1971).

A Comparison of the Hemograms of Macaca mulatto, Macaca nemestrina and Papio anubis.

Dillingham, L. A.; Morrow, A.C., and Bronsdon, M.A. 14 (3-4): 241-251 (1971).

Hydronephrosis of Pergnancy: a Naturally Occurring Disorder in Non-human Primates

Closely Resembling that in Man. Roberts, J.A. and Wolf, R.H. 15 (1-2): 143-147(1971).

The Blood Supply of the Heart in Different Monkey Species. On the Types of Myo-cardial

Blood Supply. Kantaria, P. M.

16 (3-4): 231-247 (1971).

Lung Function in Cynomolgus Monkeys and Baboons. Binns, R. and Clark, G. C. 17 (3):

209-217 (1972).

The Heart Rate in Monkeys (Baboons and Macaques) in Different Physiological States

Recorded by Radiotelemetry. Tatoyan, S. K. and Cherkovich, G. M.

17 (4): 255-266 (1972).

Blood Groups, Red Cell Enzymes and Serum Proteins of Baboons and Vervets. McDermid, E.M.; Vos, G.H., and Downing, H.J. 19 (4): 312-326 (1973). 
Heart Rate (Radiotelemetrical Registration) in Macaques and Baboons According to Dominant-Submissive Rank in a Group. Cherkovich, G.M. and Ta-

262

A Topical Guide to 'Folia Primatologica'

toyan, S.K. 20 (4): 265-273 (1973). Terrestrial Adaptations in the Hands of Cercopithecinae. Etter, H.F. 20 (5-6):

331-350 (1973). Ecological Relations and Niche Separation

between Sympatric Terrestrial Primates

in Ethiopia. Dunbar, R.I.M. and

Dunbar, E.P. 21 (1): 36-60(1974). Evolution of the Marked Chromosomes of

Primates: Experimental Evidence for

Centric Fusion. Egozcue, J. 21 (2):

148-151 (1974). Distribution of Interindividual Distances in

Patas Monkeys and Gelada Baboons.

Species and Sex Differences. Kummer,

H. 21 (3-4): 153-160(1974). Visual Acuity as Function of Wavelength

in Three Catarrhine Species. Behar, I.

and Bock, P.D. 21 (3-4): 277-289

(1974). Les associations polyspécifiques de Cerco-

pithèques du Plateau de M'passa

(Gabon). Gautier-Hion, A. et Gau-

tier, J.-P. 22 (2-3): 134-177 (1974). Muscle Spindles in Nonhuman Primate

Laryngeal Muscles. Larson, C; Sut-

ton, D., and Lindeman, R.C. 22 (4):

315-323 (1974). The Numbers of Vertebrae in Three African

Cercopithecine Species. Clauser, D. A.

23 (4): 308-319 (1975). Croissance, maturité sexuelle et sociale,

reproduction chez les cercopithécinés

forestiers africains. Gautier-Hion, A.

et Gautier, J.-P. 26 (3): 165-184 (1976). Erythroblastosis Models. II. Materno-

Fetal Incompatibility in Chimpanzee.

Wiener, A.S.; Socha, W.W., and

Moor-Jankowski, J. 27 (1): 68-74

(1977). Sequence of Eruption of Permanent Teeth

and Epiphyseal Union in Three Species

of African Monkeys. Wintheiser, J. G.;

Clauser, D.A., and Tappen, N.C 27

(3): 178-197 (1977). New Data and a Discussion of Infant Killing

in Old World Monkeys and Apes.

Angst, W. and Thommen, D. 27 (3): 198-229 (1977). Genetic Variation of Aldehyde

Dehydro-genase in Primates. Friedrichson, U.; Ritter, H., and Schmitt, J. 29 (2): 95-97

(1978).

Macaca sp.

Meiosis in Five Macaca Species. Egozcue, J. 11 (1-2): 1-16(1969). 
A Comparative Histochemical Study of the Mucins of the Nasal Fossa in Four Primates. Loo, S.K.; Kanagasun-theram, R., and Tock, E.P.C. 17 (4): 275-284 (1972).

Histomorphology of the Cervix uteri of Toque (M. sinica) and Bonnet Macaques (M. radiata). Jainudeen, M.R; Hafez, E.S.E., and Kothari, L. 18 (5-6): 469-476 (1972).

Provisional Classification and Key to Living Species of Macaques (Primates: Macaca).

Fooden, J. 25 (2-3): 225-236 (1976).

Neonatal-Maternal Weight Relationship in Macaques: An Example of Intrageneric Scaling. Leutenegger, W. 27 (2): 152-159 (1977).

New Data and a Discussion of Infant Killing in Old World Monkeys and Apes. Angst, W. and Thommen, D. 27 (3): 198-229 (1977).

M. sylvana

Parental Care in Macaca sylvana. Lahiri, R.K. and Southwick, C.H. 4 (4): 257-264 (1966).

Social Behaviour and 'Agonistic Buffering' in the Wild Barbary Macaque Macaca sylvana L.

Deag, J. M. and Crook, J. H. 15(3-4): 183-200(1971).

Geographic Distribution and Habitat Diversity of the Barbary Macaque Macaca

Systematic Index

263

sylvanus L. Taub, D.M. 27 (2): 108-133 (1977). The Annual Reproductive Cycle of Captive Macaca sylvana. Roberts, M. S. 29 (3): 229-235 (1978).

M. radiata

Some Characteristics of Adult Social and Autogrooming Patterns in two Species of Macaque.

Rosenblum, L.A.; Kauf-mann, I.C., and Stynes, A.J. 4 (6): 438-451 (1966).

The Dominant Male and Behavior Within Heterospecific Monkey Groups. Stynes, A.J.;

Rosenblum, L.A., and Kauf-mann, J.C. 9 (2): 123-134 (1968).

Evolution of the Marked Chromosomes of Primates. Experimental Evidence for Pericentric Inversion. Egozcue, J. 16 (3-4): 276-281 (1971).

The Menstrual Cycle ofthe Bonnet Monkey (Macaca radiata). Changes in Cervical Mucus Secretion, Vaginal Cytology, Sex Skin and Urinary Estrogen Excretion. McArthur, J.W.; Ovadia, J.; Smith, O.W., and Bash $\gamma$ r-Farahmand, J.: 17(1-2): 107-121(1972).

Comparaison du sommeil de deux macaques (Macaca radiata et Macaca mulatta). Bert, J.; Pegram, V. et Balzano, E. 17 (3): 202-208 (1972).

Histomorphology of the Cervix uteri of Toque (M. sinica) andBonnetMacaques (M. radiata). Jaynudeen, M. R.; Hafez, E.S.E., and Kothari, L. 18 (5-6): 469-476 (1972).

Cyclic Changes in Cervical Mucus and LH Levels in the Bonnet Macaque (Macaca radiata). Kanagawa, H.; Hafez, E. S. E.; Mori, J.; Kurosawa, T., and Kothari, L. 19 (2-3): 208-217 (1973).

Hematological Data of the Laboratory-Maintained Bonnet (Macaca radiata) and the Langur (Presbytis entellus entellus) Monkeys. Jayaraman, S.;

Hurkadli, K., and Rao, S.S. 29 (2): 98-102 (1978).

M. nemestrina

Breeding Macaca nemestrina: A Program of Birth Engineering. Kuehn, R.E.; Jensen, G.D., and Morrill, R.K.: 3 (4): 251-262 (1965).

Primate Behavioral Research in the USSR. The Sukhumi Medico-Biological Station.

Bowden, D. 4 (5): 346-360 (1966). 
Some Characteristics of Adult Social and Autogrooming Patterns in two Species of Macaque. Rosenblum, L. A.; Kauf mann, I.C., and Stynes, A.J. 4 (6): 438-451 (1966).

Hematology of the Pig-Tailed Monkey, Macaca nemestrina. Rahlmann, D. F.; Pace, N., and Barnsteyn, N.J. 5 (4): 280-284 (1967).

Congenital Renal Malformations in Monkeys. Maruffo, C. A. and Cramer, D. L. 5 (4): 305 311 (1967).

Social Status of two Hybrids in a Wild Troop of Macaca irus. Bernstein, I.S. 8 (2): 121-131 (1968).

The Dominant Male and Behavior Within Heterospecific Monkey Groups. Stynes, A. J.; Rosenblum, L. A., and Kaufman, I.C. 9 (2): 123-134 (1968).

Introductory Techniques in the Formation of Pigtail Monkey Troops. Bernstein, I.S. 10(1-2): 1-19(1969).

Activity Patterns in Pigtail Monkey Groups. Bernstein, I.S. 12 (3): 187-198 (1970).

The Hemodynamics of the Pig-tailed (Macaca nemestrina). Rahlmann, D. F.

13 (1): 1-10 1970.

A Comparison of the Hemograms of Macaca mulatta, Macaca nemestrina and Papio anubis. Dillingham, L.A.; Morrow, A.C., and Bronsdon, M.A.

14 (3-4): 241-251 (1971).

Tissues Enzyme Studies in Macaca nemestrina Monkeys. Hubbard, R.W.; 264

A Topical Guide to 'Folia Primatologica'

Hoffman, R.A., and Jenkins, D. 16 (3-4): 282-293 (1971).

Daily Activity Cycles and Weather Influences on a Pigtail Monkey Group. Bernstein, I.S. 18 (5-6): 390-415 (1972).

Muscle Spindles in Nonhuman Primate Laryngeal Muscles. Larson, C; Sut-ton, D., and Lindeman, R.C. 22 (4): 315-323 (1974).

Somatometry of Newborn Macaca neme-strina. Sirianni, J.E.; Swindler, D.R., and Tarrant, L. H. 24 (1): 16-23 (1975).

M.fascicularis

Social Status of two Hybrids in a Wild Troop of Macaca irus. Bernstein, I. S. 8 (2): 121-131 (1968).

Les jeux sociaux: Le compagnon de jeux chez les jeunes. Observations chez Macaca irus.

Fady, J.-C. 11 (1-2): 134-143 (1969).

Innervation of Oral Tissues in Some Primates. Vu, S. and Kanagasuntheram, R. 11 (4): 289299 (1969).

Defective Infants in a Feral Monkey Group. Berkson, G. 12 (4): 284-289 (1970).

Effects of Median Nerve Injury on Some Digital Tissues of the Hand of the Macaque

(Macaca fascicularis) .Wong, W.C. and Kanagasuntheram, R. 13 (1): 63-73 (1970).

On the Recessus Mesocoelicus in some Primates. Hofer, H.O. 15 (3-4): 249-263 (1971).

Follicular Morphology in Macaca fascicularis. Jewett, D. A. and Dukelow, W. R. 16 (3-4):

216-220 (1971).

The Chromosomes of the Crab-eating Macaque (Macaca fascicularis). Kana-gawa, H.; Hafez, E. S. E., and Nawar, M. 16 (3-4): 270-275 (1971).

Transferrins in Macaca irus. Lai, L.Y.C. 17 (3) 193-201 (1972).

Lung Function in Cynomolgus Monkeys 
and Baboons. Binns, R. and Clark, G.C. 17 (3): 209-217 (1972).

A Comparative Study of the Nasal Fossa of Four Nonhuman Primates. Loo, S. K. 20 (5-6):

410-422 (1973).

Comparative Study of the Histology of the Nasal Fossa in Four Primates. Loo, S. K. 21 (3-4):

290-303 (1974).

A Protracted Startle Response to Maternal Rejection in Infants of Macaca fascicularis.

Chance, M.R.A. and Jones, E. 22 (2-3): 218-236 (1974).

The Crab-Eating Macaques (Macaca fascicularis) of Angaur Island, Palau, Micronesia.

Poirier, F.E. and Smith, E.O. 22 (4): 258-306 (1974).

Histomorphology of Cervical and Uterine Epithelia of Crab-Eating Macaque, Macaca

fascicularis. David, G.F.X.; Hafez, E.S.E., and Kamash, M.A 23 (1-2): 124-134(1975).

Comparative Study of the Banding Patterns of the Chromosomes of Cercopithecidae. I.

Subfamily Papinae: Macaca fascicularis and Papio sphinx. Rubio-Goday, A.; Caballín, M.R.;

Caldés, M.G., and Egozcue, J. 26 (4): 306-309 (1976).

Factors Influencing Nursing in Macaca fascicularis. Chance, M.R.A.; Jones, E., and Shostak, S. 27 (1): $28-3 / 80$ (1977).

Chimpanzee Simian-Type Blood Groups: Reproducibility of Formerly Described Antisera and Demonstration of New Blood Groups Oc and Pcla. Moor-Jankowski, J.; Socha, W. W.; Wiener, A.S., and Plonski, H. 28 (3): 216-230 (1977).

Genetic Variation of Aldehyde Dehydro-genase in Primates. Friedrichson, U.; Ritter, H., and Schmitt, J. 29 (2): 95-97: (1978).

M. mulatta

Seasonal Cycle in Size of Testes of Free-Ranging Macaca mulatta. Sade, D.S. 2 (3): 171-180 (1964).

Systematic Index

265

The Seasonal Spermatogenic Cycle in Free Ranging Rhesus Monkeys. Conaway, C.H. and Sade, D.S. 3 (1): 1-12 (1965).

Parity as a Determinant of Birth Weight in the Rhesus Monkey. Broadhurst, P. L. and Jinks, J.L. 3 (2-3): 201-210 (1965).

An Electrocardiographic Study of Macaca mulatta. Malynow, M.R. 4 (1): 51-65 (1966).

Maternal Behavior in Primiparous and Multiparous Rhesus Monkeys. Seay, B. 4 (2): 146-168 (1966).

Twins and Teratisms in Rhesus Monkeys. Koford, C.B.; Farber, P.A., and Windle, W.F. 4 (3): 221-226 (1966).

True Hermaphrodism in a Rhesus Monkey. Sullivan, D.J. and Drobeck, H.P. 4 (4): 309-317 (1966).

Primate Behavioral Research in the USSR. The Sukhumi Medico-Biological Station.

Bowden, D. 4 (5): 346-360 (1966).

Chromosomes of Macaca mulatta Leukocytes. Farber, P. A. 4 (6): 409-415 (1966).

Vitamin B12 Nutrition in some Primates in Captivity. Oxnard, C.E. 4 (6): 424-431 (1966).

The Relationship between Growth and the Administration of Cyanocobalamin in the Rhesus Monkey. Flinn, R.M. and Oxnard, C.E. 4 (6): 432-437 (1966).

Fertility of the Colony-Born Male Macaque. Wagenen, G. van. 5 (4): 241-246 (1967). 
Die Mm. adductores femoris der niederen Altweltaffen (Cercopithecidae). Uhl-mann, K. 6 (1-2): 131-152 (1967).

Some Haematological Changes During Pregnancy in the Rhesus Monkey (Macaca mulatta). Spicer, E.J.F. and Oxnard, C.E. 6 (3-4): 236-242 (1967).

A Spontaneous Metastasizing Carcinoma of the Gallbladder in a Rhesus Monkey. O'Gara, R.W.; Kelly, M.G., and Kerber, W.T. 6 (3-4): 284-291 (1967).

A Survey of Physiological Measurements in Macaca mulatta. Stahl, W.R. and

Malinow, M.R.7(1): 12-33(1967).

Performance by a Rhesus Monkey on Three Randomly Presented Skill Sequences. Rohles, F.H., jr. 7 (3-4): 208-215 (1967).

The Vascular Pattern of the Median Eminence of the Hypophysis in the Macaque. Holmes, R.L. 7 (3-4): 216-230 (1967).

Food-Motivated Behavior in Prosimians. Ehrlich, A. 8 (1): 66-71 (1968).

Persistent Behavior Pathology in Rhesus Monkeys Following Early Social Isolation.

Mitchell, G.D. 8 (2): 132-147 (1968).

Reproduction Characteristics in a Colony of Laboratory Confined Mulatta Macaque

Monkeys. Pickering, D.E. 8 (3-4): 169-179 (1968).

Interactions Between Free-Ranging Groups of Rhesus Monkeys. Vessey, S.H. 8 (3-4): 228239 (1968).

Behavior Between two Social Groups of Rhesus Monkeys Within two Tunnel-Connected Enclosures. Marsden, H. M. 8 (3-4): 240-246 (1968).

Adenocarcinoma of the Large Intestine in a Pregnant Rhesus Monkey (Macaca mulatta).

Report of a Case. Plentl, A. A.; Dede, J. A., and Grey, R. M. 8 (3-4): 307-313 (1968).

Behavior of Free-Ranging Castrated Rhesus Monkeys. Wilson, A.P. and Vessey, S. H. 9(1): 1-14 (1968).

Thalidomide Syndrome in Rhesus Monkeys (Macaca mulatta). Barrow, M.V.; Steffek, A.J., and King, C.T.G. 10 (3): 195-203 (1969).

The 'Golden' Mulatta Macaque (Macaca mulatta): Developmental and Reproduction Characteristics in a Controlled Laboratory Environment. Pickering, D.E. and Van Wagenen, G. 11 (3): 161-166(1969).

Communication During Initial Contact: A Comparison of Squirrel and Rhesus Monkeys.

Castell, R. 11 (3): 206-214 (1969).

266

A Topical Guide to 'Folia Primatologica'

Immunoglobulin Levels in the Macaca

mulatto. Eitzman, D. V. 12 (4): 313-316

(1970). Vibrissae Structure in the Rhesus Monkey.

Van Horn, R. N. 13 (4): 241-285 (1970). Peri-Menstrual Sexual Behavior Among

Rhesus Monkeys. Loy, J. 13 (4): 286-

297 (1970). Luteinizing Hormone Levels in Nonhuman

Primates. Blakley, G.A. 13 (4): 298-

305 (1970). Intrarenal Arterial Patterns in Nonhuman

Primates. Stynson, J. M. 14 (1-2): 70-79

(1971). Flexion and Metric Age Changes of the

Cranial Base in the Macaca mulatta. I. 
Infant and Juveniles. Michejda, M. and

Lamey, D. 14 (1-2): 84-94 (1971). A Comparison of the Hemograms of Macaca mulatta, Macaca nemestrina and

Papio anubis. Dillingham, L. A.; Morrow, A.C., and Bronsdon, M.A. 14

(3-4): 241-251 (1971). Social Entrainment of the Feeding Behavior

in Monkeys. Rohles, F.H., jr. 15 (1-2):

58-64 (1971). On the Recessus Mesocoelicus in some

Primates. Hofer, H.O. 15 (3-4): 249-

263 (1971). Evolution of the Marked Chromosomes of

Primates. Experimental Evidence for

Pericentric Inversion. Egozcue, J. 16

(3-4): 276-281 (1971). Comparaison du sommeil de deux macaques

(Macaca radiata et Macaca mulatta).

Bert, J.; Pegram, V. et Balzano, E.

17 (3): 202-208 (1972). On the Question of Vagal Tone in Monkeys

(Macaca mulatta). Cherkovich, G.M.

and Tatoyan, S.K. 17 (4): 248-254

(1972). The Heart Rate in Monkeys (Baboons and

Macaques) in Different Physiological

States Recorded by Radiotelemetry.

Tatoyan, S. K. and Cherkovich, G. M.

17 (4): 255-266 (1972).

Learning-Set Formation and Transfer in Rhesus andTalapoin Monkeys. Schrier, A.M. 17 (56): 389-396 (1972).

Gonadotrophin Concentrations in the Placentae of Man, the Rhesus Monkey and the

Marmoset. Hobson, B.M. 18 (1-2): 35-40 (1972).

Intergroup Behavior of Free-Ranging Rhesus Monkeys (Macaca mulatta). Hausfater, G. 18 (1-2): 78-107 (1972).

Sociometrics of Macaca mulatta. I. Linkages and Cliques in Grooming Matrices. Sade, D.S. 18 (3-4): 196-223 (1972).

New Observations on the Excretion of Chorionic Gonadotrophin During Pregnancy in the Rhesus Monkey (Macaca mulatta). Hobson, B.M. 18 (5-6): 463-468 (1972).

An X-O Anomaly and Ovarian Dysgenesis in a Rhesus Monkey. Weiss, G.; Weick, R.F.;

Knobil, E.; Wolman, S.R., and Gorstein, F. 19 (1): $24-27$ (1973).

Chromosomal Evolution in a Rhesus Cell Line. Pasztor, L. M. and Hu, F. 19 (1): 28-34

(1973).

Social Behavior Comparison in Laboratory-Reared Stumptail and Rhesus Macaques.

Chamove, A.S. 19 (1): 35-40 (1973).

Ovarian Steroid Patterns in Peripheral Plasma during the Menstrual Cycle in the Rhesus

Monkey. Bosu, W.T.K.; Johansson, E.D.B., and Gemzell, C. 19 (2-3): 218-234 (1973).

Changes in the Sexual Behaviour of Male Rhesus Monkeys (M. mulatta) at Puberty.

Comparisons with the Behaviour of Adults. Michael, R.P. and Wilson, M. 19 (5): 384-403

(1973).

Quality and Intensity of Sugar Solutions as Determinants of Ingestion by the Rhesus Monkey

(Macacamulatta). Maller, O. 20(1): $72-77$ (1973). 
Interrelationship of Blood Groups between Rhesus Macaques (Macaca mulatta) and Celebes Ape (Macaca niger). La Salle, M. 20 (2-3): 95-105 (1973).

Systematic Index

267

Considerations on Function in Macaque

Dermatoglyphics. Meier, R. J. 20 (2-3):

112-124(1973). Parental Care in a Group of Free-Ranging

Rhesus Monkeys (Macaca mulatto).

Breuggeman, J.A. 20 (2-3): 178-210

(1973). Heart Rate (Radiotelemetrical Registration)

in Macaques and Baboons According to

Dominant-Submissive Rank in a Group.

Cherkovich, G. M. and Tatoyan, S. K.

20 (4): 265-273 (1973). A Ten-Year Summary of Reproductive

Data for Free-Ranging Macaca mulatta.

Drickamer, L.C. 21 (1): 61-80 (1974). Aggression and Social Controls in Rhesus

Monkey (Macaca mulatta) Groups

Revealed in Group Formation Studies.

Bernstein, I.S.; Gordon, T.P., and

Rose, R.M. 21 (2): 81-107 (1974). Reactions of Infant Monkeys to Social and

Nonsocial Stimuli. Baldwin, D.V. and

Suomi, S. J. 22 (4): 307-314 (1974). Muscle Spindles in Nonhuman Primate

Laryngeal Muscles. Larson, C; Sut-

ton, D., and Lindeman, R.C. 22 (4):

315-323 (1974). Healed Fractures in Macaca mulatta: Age,

Sex, and Symmetry. Buikstra, J. E. 23

(1-2): 140-148 (1975). Rank, Rhesus Social Behavior, and Stress.

Chamove, A.S. and Bowman, R.E. 26

(1): 57-66 (1976). Effects of Geographic Transfer on the

Timing of Seasonal Breeding of Rhesus

Monkeys. Varley, M.A. and Vessey,

S.H. 28(1): 52-59 (1977).

M. $\operatorname{arctoides}(\approx \mathrm{M}$. speciosa $)$

Identification of the Stump-Tailed Monkey, Macaca speciosa I. Geoffrey, 1826. Fooden, J. 5

(3): 153-164 (1967).

Chromosomes and DNA Synthesis in the Stumptail Monkey (Macaca speciosa), with Special

Regard to Marker and Sex

Chromosomes. Huang, C. C.; Habbitt, H., and Ambrus, J.L. 11 (1-2): 28-34 (1969).

Comparative Biochemistry of the Primates. II. The Indole Compounds of Primate Blood and

Urine. Smith, I. and Lerner, R.P. 14 (1-2): 110-117 (1971).

Social Behavior Comparison in Laboratory-Reared Stumptail and Rhesus Macaques.

Chamove, A.S. 19 (1): 35-40 (1973).

Harassment of Sexual Behavior in the Stumptail Macaque, Macaca arctoides. Gouzoules, H. 22 (2-3): 208-217 (1974). 
Effect of Parturition and Group Composition on Competitive Drinking Order in Stumptail Macaques (Macaca arctoides). Weisbard, C. and Goy, R.W. 25 (2-3): 95-121 (1976).

Some Effects of Living Conditions upon the Pattern of Growth in the Stumptail Macaque (Macaca arctoides). Fau-cheux, B.; Bertrand, M., and Bour-lière, F. 30 (3): 220-236 (1978). M.fuscata

Identification of the Stump-Tailed Monkey, Macaca speciosa I. Geoffroy, 1826.

Fooden, J. 5 (3): 153-164 (1967). The Electrocardiogram of Macaca fuscata. Malinow, M. R. and DeLannoy, C.W., jr. 7 (3-4): 284-291 (1967). Social Organization of a Troop of Japanese Monkeys in a Two-Acre Enclosure. Alexander, B.K. and Bowers, J.M.

10 (3): 230-242 (1969). The Sexual Behavior of a Confined Troop of Japanese Macaques. Hanby, J.P.; Robertson, L.T., and Phoenix, C.H. 16 (1-2): 123-143 (1971). Intra-Group Variations in the Dental Eruption Sequence of Macaca fuscata fuscata. Nass, G.G. 28 (4): 306-314 (1977).

268

A Topical Guide to 'Folia Primatologica'

M. nigra

Simian Blood Groups. A 'New' Blood Factor, Aba, of Celebes Black Ape Red Cells Demonstrated with Rabbit Anti-sera. Moor-Jankowski, J.; Wiener, A.S.; Gordon, E.B., and Guthrie, C.B. 3 (4): 245-250 (1965).

The Electrocardiogram of Cynopithecus niger. Malinow, M. R. and DeLannoy, C.W. 4(1): 66-73 (1966).

Serum and Red-Cell Protein Variations of the Celebes Black Ape. Jolly, C. J. and Barnicot, N.A. 4 (3): 206-220 (1966).

Interrelationship of Blood Groups between Rhesus Macaques (Macaca mulatto) and Celebes Ape (Macaca niger). La Salle, M. 20 (2-3): 95-105 (1973).

Cercocebus sp.

Red Cell and Serum Proteins of Cercocebus, Presbytis, Colobus and Certain Other Species. Barnicot, N. A. and Hewett-Emmett, D. 17 (5-6): 442-457 (1972).

The Numbers ofVertebrae in Three African Cercopithecine Species. Clauser, D. A. 23 (4): 308-319 (1975).

Postreproductive Survival and Behavior in a Free-Ranging Female Mangabey. Waser, P.M. 29 (2): 142-160 (1978).

C. albígena

Group Composition, Ecology and Daily Activities of Free Living Mangabeys in Uganda. Chalmers, N.R. 8 (3-4): 247-262 (1968).

The Social Behaviour of Free Living Mangabeys in Uganda. Chalmers, N.R. 8 (3-4): 263-281 (1968).

Comparative Ecology of Cercocebus albi-gena (Gray) and Cercocebus torquatus (Kerr) in Rio Muni, West Africa. Jones, C. and Sabater Pi, J. 9 (2)- 99- 
113(1968). The Visual and Vocal Communication of

Free Living Mangabeys in Uganda.

Chalmers, N.R. 9 (3-4): 258-280

(1968). Reproductive Cycles of the Mangabey

Cercocebus albigena. Rowell, T.E. and

Chalmers, N. R. 12 (4): 264-272 (1970). Behaviour and Female Reproductive Cycles

in a Captive Group of Mangabeys.

Chalmers, N.R. and Rowell, T.E. 14

(1-2): 1-14(1971). Sequence of Eruption of Permanent Teeth

and Epiphyseal Union in Three Species

of African Monkeys. Wintheiser, J. G.;

Clauser, D.A., and Tappen, N.C. 27

(3): 178-197 (1977).

C. torquatus

Comparative Ecology of Cercocebus albigena (Gray) and Cercocebus torquatus (Kerr) in Rio

Muni, West Africa. Jones, C. and Sabater Pi, J. 9 (2): 99-113 (1968).

The Distribution of the White-Collared Mangabey, Cercocebus torquatus, in Nigeria.

Schlitter, D.A.; Phillips, J., and Kemp, G.E. 19 (5): 380-383 (1973).

The Red Crowned Mangabey, Cercocebus torquatus, in Western Nigeria. Happold, D.C.D. 20

(5-6): 423-428 (1973).

C. atys

Activity Patterns in a Sooty Mangabey Group. Bernstein, I.S. 26 (3): 185-206 (1976).

Papio sp.

Serum and Red-Cell Protein Variations of the Celebes Black Ape. Jolly, C. J. and Barnicot, N.A. 4 (3): 206-220 (1966).

Systematic Index

269

A Problem in Evolutionary Systematics: Nomenclature and Classification of Baboons, Genus Papio. Buettner-Janusch, J. 4 (4): 288-308 (1966).

A Single Umbilical Artery in the Baboon. Hendrickx, A. G. and Katzberg, A. A. 5 (4): 295304 (1967).

A Description of a Diaphragmatic Hernia in a Sixteen Week Baboon Fetus (Papio sp.).

Hendrickx, A.G. and Gasser, R.F. 7(1): 66-74 (1967).

The Mycoflora of the Subhuman Primates. III. The Flora of the Skin of the Baboon, Vervet, and Gelada in Captivity. Al-Doory, Y. 7 (3-4): 292-298 (1967).

Observations on the Vasculature of the Baboon Placenta (Papio sp.) with Special Reference to the Transverse Communicating Artery. Houston, M. L. and Hendrickx, A.G. 9 (1): 68-77 (1968).

The Effect of Temporary Separation from Their Group on the Mother Infant Relationship of Baboons. Rowell, T.E. 9(2): 114-122(1968).

The Visual and Vocal Communication of Free Living Mangabeys in Uganda. Chalmers, N.R. 9 (3-4): 258-280 (1968).

Intrarenal Arterial Patterns in Nonhuman Primates. Stinson, J. M. 14 (1-2): $70-79$ (1971).

Unilateral Renal Aplasia in an African Baboon (Papio sp.J. Kim, C.S. and Kalter, S.S. 17 (1-

2): 157-159 (1972). 
Blood Groups, Red Cell Enzymes and Serum Proteins of Baboons and Vervets. McDermid, E.M.; Vos, G.H., and Downing, H.J. 19 (4): 312-326 (1973).

A New Taxonomic Tool. II. Serological Differences between Baboons and Ge-ladas Demonstrated by Cross-Immunization. Moor-Jankowski, J.; Wiener, A.S., and Socha, W.W. 22 (1): 59-71 (1974).

New Data and a Discussion of Infant Killing in Old World Monkeys and Apes.

Angst, W. and Thommen, D. 27 (3): 198-229 (1977).

P. anubis

Hemoglobins and Transferrins of Baboons. Buettner-Janusch, J. 1 (2): $73-87$ (1963).

Cardiovascular Function in Adult Baboons as Indicated by Standard Diagnostic Tests.

Citters, R. L. van and Lasry, J. E. 3 (1): 13-21 (1965).

Changing Dynamics in the Germinal Centers of the Spleen of the East Africa Baboon, Papio anubis. Katzberg, A. A. and Ungerleider, G.K. 7 (1): 75-80 (1967).

Changing Dynamics in the Thyroid Follicles of the Baboon, Papio anubis. Katzberg, A.A. 8 (1): 58-65 (1968).

Ecological and Behavioural Contrasts Between Sympatric Ground Dwelling Primates in

Ethiopia. Crook, J.H. and Aldrich-Blake, P. 8 (3-4): 192-227 (1968).

Respiratory Characteristics of the Blood of the Baboon, Gibbon, and Chimpanzee. Parer, J.T. and Moore, C.P. 9 (2): 154-159(1968).

Long-Term Changes in a Population of Ugandan Baboons. Rowell, T. 11 (4): 241-254 (1969).

A Comparison of the Hemograms oîMacaca mulatta, Macaca nemestrina and Papio anubis.

Dillingham, L.A.; Morrow, A.C., and Brondson, M.A. 14 (3^0: 241-251 (1971).

Observations on Baboons, Papio anubis, in an Arid Region in Ethiopia. Aldrich-Blake, F.P.G.; Bunn, T.K.; Dunbar, R.I.M., and Headley, P.M. 15 (1-2): 1-35 (1971).

Adult Male-Infant Relations among Baboons (Papio anubis). Ransom, T.W. and Ransom, B.S. 16 (3-4): 179-195 (1971).

270

A Topical Guide to 'Folia Primatologica'

The Order of Movement of Adult Male and Black Infant Baboons (Papio anubis) Entering and Leaving a Potentially Dangerous Clearing. Rhine, R.J. and Owens, N.W. 18 (3-4): 276283 (1972).

A Comparison of Anubis Baboons, Hama-dryas Baboons and Their Hybrids at a Species Border in Ethiopia. Nagel, U. 19 (2-3): 104-165 (1973).

Ecological Relations and Niche Separation between Sympatric Terrestrial Primates in Ethiopia. Dunbar, R. I. M. and Dun-bar, E.P. 21 (1): 36-60 (1974).

Ranging Patterns of a Troop of Baboons (Papio anubis) in Kenya. Harding, R.S.O. 25 (2-3): 143-185 (1976).

Competition for Meat between Chimpanzees and Baboons of the Gombe National Park.

Morris, K. and Goodall, J. 28 (2): 109-121 (1977).

A Note on the Birth of a Baboon (Papio anubis). Love, J.A. 29 (4): 303-306 (1978).

The Order of Movement of Yellow Baboons (Papio cynocephalus). Rhine, R.J. 23 (1-2): $72-$ 104(1975).

Scanning Electron Microscopy of Baboon Spermatozoa. FIéchon, J.-E.; Krae-mer, D.C., and Hafez, E.S.E. 26 (1): 24-35 (1976). 
Tail Carriage in Baboons (Papio cynocephalus): Relationship to Dominance Rank and Age. Hausfater, G. 27 (1): 41-59 (1977).

Differential Habitat Utilization of Four Cercopithecidae in a Kenyan Forest. Moreno-Black, G. and Maples, W. R. 27 (2): 85-107 (1977).

Genetic Variation of Aldehyde Dehydro-genase in Primates. Friedrichson, U.; Ritter, H., and Schmitt, J. 29 (2): 95-97 (1978).

The Nature of a Primary Feeding Habit in Different Age-Sex Classes of Yellow Baboons (Papio cynocephalus). Rhine, R.J. and Westlund, B.J. 30 (1): 64-79 (1978).

P. cynocephalus

Excretion of Gonadotrophin by the Pregnant Baboon (Papio cynocephalus). Hobson, B.M. 12 (2): 111-115 (1970).

Multivariate Discriminant Analysis Applied to Cranial Features of Papio ursinus and P. cynocephalus. Booth, S.N. and Freedman, L. 12 (4): 296-304 (1970).

Supernumerary Nipples in the Baboon (Papio cynocephalus). Buss, D.H. and Hamner III, J.E. 16 (1-2): 153-158 (1971).

Lung Function in Cynomolgous Monkeys and Baboons. Binns, R. and Clark, G.C. 17 (3): 209-217 (1972).

The Occurrence of Baboon-Type IgG Subclass Antigenic Determinants within the Order Primates. Damian, R.T.; Luker, M. F.; Greene, N.D., and Kalter, S. S. 17 (5-6): 458-474 (1972).

P. papio

Le sommeil nocturne chez le babouin Papio papio. Observations en milieu naturel et données électrophysiologiques. Bert, J.; Ayats, H.; Martino, A. et Collomb, H. 6(1-2):28^₫3(1967).

Note sur Torganisation de la vigilance so-ciale chez le babouin Papio papio dans $\Gamma$ Est

Sénégalais. Bert, J.; Ayats, H.; Martino, A. et Collomb, H. 6 (1-2): 44-47 (1967).

Luteinizing Hormone Levels in Nonhuman Primates. Blakley, G.A. 13 (4): 298-305 (1970).

Social Organization of the Guinea Baboon, Papio papio. Dunbar, R.LM. and Nathan, M.F. 17 (5-6): 321-334(1972).

Modifications du comportement du babouin Papio papio dans son milieu na-

Systematic Index

271

turel par Гapport d'aliments. Balzano, E.; Guillon, R.; Forni, C.; Fady, J. C. et Bert, J. 19 (5): 404-408 (1973). Muscle Spindles in Nonhuman Primate Laryngeal Muscles. Larson, C; Sutton, D., and Lindeman, R.C. 22 (4): 315-323 (1974).

P. ursinus

Hemoglobins and Transferrins of Baboons. Buettner-Janusch, J. 1 (2): $73-87$ (1963).

The Menstrual Cycle and Sexual Behaviour in a Troop of Free Ranging Chacma Baboons

(Papio ursinus). Saayman, G.S. 12 (2): 81-110 (1970).

Multivariate Discriminant Analysis Applied to cranial Features of Papio ursinus and P.

cynocephalus. Booth, S.N. and Freedman, L. 12 (4): 296-304 (1970).

The Baboon (Papio ursinus) Heart (Coronary Blood Supply, Muscle Function and Metabolism). Brink, A.J.; Lewis, C. M.; Bosman, A. R., and Lochner, A. 13(1): 11-22 (1970). 
Behaviour of the Adult Males in a Troop of Free-ranging Chacma Baboons (Papio ursinus). Saayman, G. S. 15 (1-2): 36-57 (1971).

Grooming Behaviour in a Troop of Free-ranging Chacma Baboons (Papio ursinus). Saayman, G.S. $16\left(3^{\wedge} \mathrm{t}\right): 161-178(1971)$.

Effects of Ovarian Hormones upon the Sexual Skin and Mounting Behaviour in the Freeranging Chacma Baboon (Papio ursinus). Saayman, G.S. 17 (4): 297-303 (1972).

Troop-Mobilizing Behavior of Adult Male Chacma Baboons. Buskirk, W.H.; Buskirk, R.E., and Hamilton III, W.J. 22(1): 9-18 (1974).

P. hamadryas

Social Units of a Free-Living Population of Hamadryas Baboons. 1 (1): 4-19 (1963).

Primate Behavioral Research in the USSR. The Sukhumi Medico-Biological Station.

Bowden, D. 4 (5): 346-360 (1966).

Heart Rate in Monkeys (Baboons and Macaques) in Different Physiological States Recorded by Radiotelemetry. Tatoyan, S. K. and Cherkovich, G. M. 17 (4) 255-266 (1972).

On the Corpus adiposum buccae (Bichat) in Pan troglodytes. Hofer, H.O. 17 (5-6): 434-441

(1972).

A Comparison of Anubis Baboons, Hamadryas Baboons and Their Hybrids at a Species

Border in Ethiopia. Nagel, U. 19 (2-3): 104-165 (1973).

Heart Rate (Radiotelemetrical Registration) in Macaques and Baboons According to

Dominant-Submissive Rank in a Group. Cherkovich, G.M. and Tatoyan, S.K. 20 (4): 265-

273 (1973).

Field Observation of a Birth in Hamadryas Baboons. Abegglen, H. and Abegglen, J.-J. 26(1):

54-56 (1976).

Mandrillus sphinx

Notes on Two Anomalies in Mandrills (Mandrillus sphinx Linn.). Hill, W. C. O. and Sabater Pi, J. 12 (4): 290-295 (1970).

Contribution to the Ecology of Mandrillus sphinx Linnaeus 1758 of Rio Muni (Republic of Equatorial Guinea). Sabater Pi, J. 17 (4): 304-319 (1972).

Distribution, Divergence and Speciation of the Drill and Mandrill. Grubb, P. 20 (2-3): 161-

177(1973).

Comparisons of Spatial and Orientational Relationships as Manifestations of Divergent Modes of Social Organization in Captive Groups of Mandrillus sphinx and Theropithecus gelada. Emory, G. R.

272

A Topical Guide to 'Folia Primatologica'

24 (4): 293-314 (1975). Comparative Study of the Banding Patterns of the Chromosomes of Cercopithecidae. I. Subfamily Papinae: Macaca fascicu-laris and Papio sphinx. Rubio-Goday, A. Caballín, M.R.; Caldés, M.G., and Egozcue, J. 26 (4): 306-309 (1976).

Theropithecus gelada

The Mycoflora of the Subhuman Primates. III. The Flora of the Skin of the Baboon, Vervet, and Gelada in Captivity. Al-Doory, Y. 7 (3-4): 292-298 (1967).

Ecological and Behavioural Contrasts Between Sympatric Ground Dwelling Primates in

Ethiopia. Crook, J.H. and Aldrich-Blake, P. 8 (3-4): 192-227 (1968).

Ecological Relations and Niche Separation between Sympatric Terrestrial Primates in Ethiopia. Dunbar, R.I.M. and Dunbar, E.P. 21 (1): 36-60 (1974). 
Distribution of Interindividual Distances in Patas Monkeys and Gelada Baboons. Species and Sex Differences. Kummer, H. 21 (3-4): 153-160 (1974).

A New Taxonomic Tool. II. Serological Differences between Baboons and Ge-ladas Demonstrated by Cross-Immunization. Moor-Jankowski, J.; Wrener, A.S., and Socha, W.W. 22 (1): 59-71 (1974).

Activity Patterns in a Gelada Monkey Group. Bernstein, I.S. 23 (1-2): 50-71 (1975).

Comparisons of Spatial and Orientational Relationships as Manifestations of Divergent Modes of Social Organization in Captive Groups of Mandrülus sphinx and Theropithecus gelada. Emory, G.R. 24 (4): 293-314 (1975).

New Data and a Discussion of Infant Killing in Old World Monkeys and Apes. Angst, W. and Thommen, D. 27 (3): 198-229 (1977).

Cercopithecus sp.

Über die Variabilität der präbasialen Ky-phose bei der Gattung Cercopithecus. Pawlik, M. 5 (3): 201-212 (1967).

Position of the Centromere in the Marked Acrocentric Chromosomes of Primates. Egozcue, J. 7 (3-4): 238-242 (1967).

A Fertile Hybrid Between Two Cercopithecus spp. in the Budongo Forest, Uganda. AldrichBlake, F.P.G. 9 (1): 15-21 (1968).

Zur Variabilität des Hautleistensystems der Meerkatzen (Cercopithecus) und des Husarenaffen (Erythrocebus patas). Brehme, H. 9 (1): 41-67 (1968).

Learning: A Comparative Study of Lemur and Cercopithecus. Rumbaugh, D.M. and Arnold, R.C. 14 (3-4): 154-160 (1971).

Extinction: A Comparative Primate Study of Lemur and Cercopithecus. Arnold, R.C. and Rumbaugh, D.M. 14 (3-4): 161-170 (1971).

New Fossil Cercopithecus Material from the Lower Omo Basin, Ethiopia. Ecк, G. and Howell, F. C. 18 (5-6): 325-355 (1972).

Croissance, maturité sexuelle et sociale, reproduction chez les cercopithécinés forestiers africains. Gautier-Hion, A. et Gautier, J.-P. 26 (3): 165-184 (1976).

Differential Habitat Utilization of Four Cercopithecidae in a Kenyan Forest. Moreno-Black, G. and Maples, W.R. 27 (2): 85-107 (1977).

Sequence of Eruption of Permanent Teeth and Epiphyseal Union in Three Species of African Monkeys. Wrntheiser, J.G.; Clauser, D.A., and Tappen, N.C. 27 (3): 178-197 (1977).

New Data and a Discussion of Infant Killing in Old World Monkeys and Apes. Angst, W. and Thommen, D. 27 (3): 198-229 (1977).

Systematic Index

273

C.aethiops

Etude électroencéphalographique de deux cynomorphes de ГOuest Africain. Bert, J. and Collomb, H. 1 (3-4): 137-149 (1963).

Observations on the Menstrual Cycle of the Grivet Monkey (Cercopithecus aethiops aethiops) in the Sudan. Butler, H. 4 (3): 194-205 (1966).

Structure and Function in Primate Society. Gartlan, J.S. 8 (2): 89-120 (1968).

L'électroencéphalogramme du sommeil chez les Cercopithecinae: Erythrocebus patas et Cercopithecus aethiops sabaeus. Bert, J. et Pegram, V. 11 (1-2): 151-159 (1969). 
Red Cell and Serum Proteins of Talapoin, Patas and Vervet Monkeys. Barnicot, N. A. and Hewett-Emmett, D. 15 (1-2): 65-76(1971).

Play-mothering: The Relations between Juvenile Females and Young Infants among Freeranging Vervet Monkeys (Cercopithecus aethiops). Lancaster, J.B. 15 (3-4): 161-182 (1971). The St. Kitts Green Monkey (Cercopithecus aethiops sabaeus): Ecology, Population Dynamics, and Selected Behavioral Traits. Poirier, F.E. 17 (1-2): 20-55 (1972).

Red Cell Enzymes and Serum Proteins of Cercopithecus aethiops (South African Green Monkey). McDermid, E. M. and Ananthakrishnan, R. 17 (1-2): 122-131 (1972).

New Fossil Cercopithecus Material from the Lower Omo Basin, Ethiopia. Eck, G. and Howell, F.C. 18 (5-6): 325-355 (1972).

Ecological Relations and Niche Separation between Sympatríc Terrestrial Primates in Ethiopia. Dunbar, R.I.M. and Dunbar, E.P. 21 (1): 36-60 (1974).

Evolution of the Marked Chromosomes of Primates: Experimental Evidence for Centric Fusion. Egozcue, J. 21 (2):

148-151 (1974). Differential Habitat Utilization of Four

Cercopithecidae in a Kenyan Forest.

Moreno-Black, G. and Maples, W.R.

27 (2): 85-107 (1977). Sequence of Eruption of Permanent Teeth

and Epiphyseal Union in Three Species

of African Monkeys. Wrntheiser, J. G.;

Clauser, D.A., and Tappen, N.C. 27

(3): 178-197 (1977). Genetic Variation of Aldehyde Dehydro-

genase in Primates. Friedrichson, U.;

Ritter, H., and Schmitt, J. 29 (2):

95-97 (1978). The Diet and Feeding Behaviour of Cercopithecus aethiops tantalus.

Kavanagh,

M. 30(1): 30-63 (1978).

C. mitis

Territories and Movements of Sykes Monkeys \{Cercopithecus mitis kolbi Neu-man) in Kenya. De Vos, A. and Omar, A. 16(3-4): 196-205(1971).

The Annual Reproductive Cycle of an African Monkey (Cercopithecus mitis kolbi Neuman).

Omar, A. and De Vos, A. 16 (3-4): 206-215 (1971).

Differential Habitat Utilization of Four Cercopithecidae in a Kenyan Forest. Moreno-Black,

G. and Maples, W.R. 27 (2): 85-107 (1977).

C. campbelli

Le comportement social de la Mone de Lowe (Cercopithecus campbelli lowei). Hunkeler, C;

Bourlière, F. et Ber-trand, M. 17 (3): 218-236 (1972).

C. (Miopithecus) talapoin

L'organisation sociale d'une bande de Talapoins (Miopithecus talapoin) dans

274

A Topical Guide to 'Folia Primatologica'

le Nord-Est du Gabon. Gautier-Hion, A. 12(2): 116-141 (1970).

Composition of Milk from Talapoin Monkeys. Buss, D.H. and Cooper, R.W. 13 (2-3): 196-

206 (1970). 
Red Cell and Serum Proteins of Talapoin, Patas and Vervet Monkeys. Barnicot, N. A. and Hewett-Emmett, D. 15 (1-2): 65-76 (1971).

Learning-Set Formation and Transfer in Rhesus and Talapoin Monkeys. Schrier, A. M. 17 (56): 389-396 (1972).

Communication among Captive Talapoin Monkeys (Miopithecus talapoin). Wolf-heim, J.H. and Rowell, T.E. 18 (3-4): 224-255 (1972).

Croissance, maturité sexuelle et sociale, reproduction chez les cercopithécinés forestiers africains. Gautier-Hion, A. et Gautier, J.-P. 26 (3): 165-184 (1976).

A Quantitative Analysis of the Organization of a Group of Captive Talapoin Monkeys (Miopithecus talapoin). Wolf-hem, J.H. 27 (1): 1-27 (1977).

Variation in Age at Puberty in Monkeys. Rowell, T.E. 27 (4): 284-296 (1977).

Reproductive Cycles of the Talapoin Monkey (Miopithecus talapoin). Rowell, T.E. 28 (3): 188-202 (1977).

C. nigroviridis

Die Mm. adductores femoris der niederen Altweltaffen (Cercopithecidae). Uhl-mann, K. 6 (1-2): 131-152 (1967).

Erythrocebus patas

Etude électroencéphalographique de deux cynomorphes de ГOuest Africain. Bert, J. and

Collomb, H. 1 (3-4): 137-149 (1963).

Behaviour of Patas Monkeys, Erythrocebus patas, in Captivity, with Notes on the Natural Habitat. Hall, K.R.L.; Boel-

kins, R.C., and Goswell, M.J. 3 (1): 22-49 (1965).

Pregnancy, Birth and Early Infant Behaviour in the Captive Patas Monkey Erythrocebus patas. Goswell, M.J. and Gartlan, J.S. 3 (2-3): 189-200 (1965).

Hand Preferences and Dexterities of Captive Patas Monkeys. Hall, K. R. L. and Mayer, B. 4 (3): 169-185 (1966).

Vitamin B12 Nutrition in some Primates in Captivity. Oxnard, C.E. 4 (6): 424-431 (1966). Social Interactions in a Group of Captive Patas Monkeys (Erythrocebus patas). Hall, K.R.L. and Mayer, B. 5 (3): 213-236(1967).

Zur Variabilität des Hautleistensystems der Meerkatzen (Cercopithecus) und des Husarenaffen (Erythrocebus patas). Brehme, H. 9 (1): 41-67 (1968).

L'électroencéphalogramme du sommeil chez les Cercopithecinae: Erythrocebus patas et Cercopithecus aethiops sabaeus. Bert, J.etPEGRAM, V. 11 (1-2): 151-159 (1969).

Adrenal Cortical Rests of the Ovarian Hilus of the Patas Monkey. Conaway, C.H. 11 (3): 175-180(1969).

Placenta Previa in a Patas Monkey (Erythrocebus patas). Wolf, R.H. 14 (1-2): 80-83 (1971). Red Cell and Serum Proteins of Talapoin, Patas and Vervet Monkeys. Barnicot, N. A. and Hewett-Emmett, D. 15 (1-2): 65-76 (1971).

Red Cell and Serum Proteins of Patas Monkeys, Cercopithecus (= Erythrocebus) patas. Allen, R.C. and Buett-ner-Janusch, J. 20 (5-6): 321-330 (1973).

Distribution of Interindividual Distances in Patas Monkeys and Gelada Baboons. Species and Sex Differences. Kummer, H. 21 (3-4): 153-160 (1974).

Changes in Facial Color Associated whit Pregnancy in Patas Monkeys. Loy, J. 22 (4): 251 257 (1974).

Systematic Index

275 
Variation in Age at Puberty in Monkeys. Rowell, T.E. 27 (4): 284-296 (1977).

Colobinae

Zur Kenntnis von Bau und Funktion des Magens der Schlankaffen (Colobinae). Kuhn, H.-J. 2

(4): 193-221 (1964).

The Maintenance of Langurs (Colobidae) in Captivity; Experiences and Some Suggestions.

Hill, W.C. Osman. 2 (4): 222-231 (1964).

Red Cell and Serum Proteins of Cercocebus, Presbytis, Colobus and Certain Other Species.

Barnicot, N. A. and Hewett-Emmett, D. 17 (5-6): 442^157 (1972).

Evolution of the Marked Chromosomes of Primates: Experimental Evidence for Centric

Fusion. Egozcue, J. 21 (2): 148-151 (1974).

Affinities of Tertiary Hominoid Femora. McHenry, H. M. and Corruccini, R. S. 26(2): 139150 (1976).

Presbytis entellus

Waschen bei zwei Arten der Gattung Presbytis (Cercopithecoidea, Primates). Lo-renz, R. 4 (3): 191-193 (1966).

Unilateral Hypoplasia of the Kidney of a Female Langur Presbytis entellus entellus Dufresne.

David, G.F.X. and Ramas-wami, L.S. 5 (4): 312-315 (1967).

Studies on Menstrual Cycles and Other Related Phenomena in the Langur \{Presbytis entellus entellus). David, G.F.X. and Ramaswami, L.S. 11 (4): 300-316 (1969).

The Pituitary Gland of the North Indian Langur (Presbytis entellus entellus Dufresne). David, G.F.X. and Ramaswami, L.S. 16 (1-2): 52-73 (1971).

XX Male Presbytis entellus? A Retrospective Study. Egozcue, J. 17 (4): 292-296 (1972).

Male-Male Competition and Infanticide Among the Langurs (Presbytis entellus) Of Abu, Rajasthan. Hrdy, S.B. 22 (1): 19-58 (1974).

Protein Polymorphism in the Hanuman Langur (Presbytis entellus). Hrdy, D.B.; Barnicot, N.A., and Alper, C.A. 24 (2-3): 173-187 (1975).

New Data and a Discussion of Infant Killing in Old World Monkeys and Apes. Angst, W. and Thommen, D. 27 (3): 198-229 (1977).

P. senex

The Reproductive Cycles of Two Subspecies of Purple-Faced Langurs (Presbytis senex) with Relation to Environmental Factors. Rudran, R. 19 (1): 41-60 (1973).

Adult Male Replacement in One-Male Troops of Purple-Faced Langurs (Presbytis senex senex) and Its Effect on Population Structure. Rudran, R. 19 (2-3): 166-192(1973).

P.johnii

The Nilgiri Langur (Presbytis johnii) Troop: Its Composition, Structure, Function and Change. Poirier, F.E.

10 (1-2): 20-47 (1969).

Behavioral Flexibility and Intertroop Variation Among Nilgiri Langurs (Presbytis johnii) of South India. Poirier, F.E.

11 (1-2): 119-133 (1969).

Dominance Structure of the Nilgiri Langur

(Presbytis johnii) of South India. Poirier, F.E. 12 (3): 161-186 (1970). The Communication Matrix of the Nilgiri Langur (Presbytis johnii) of South India. Poirier, F.E. 13 (2-3): 92-136 (1970).

276 


\section{A Topical Guide to 'Folia Primatologica'}

P. cristatus

Über die Variabilität und Veränderungen der präbasialen Kyphose während der postnatalen Ontogenese bei Colobinen-schädeln. Angst, R. 8 (3-4): 301-306 (1968).

Protein Polymorphism in the Hanuman Langur (Presbytis entellus). Hrdy, D. B. Barnicot, N.A., and Alper, C.A. 24 (2-3): 173-187 (1975).

Pygathrix nemaeus

Karyotype Abnormalities in Two Primate Species, Pygathrix nemaeus and Lemur coronatus. Bogart, M.H. and Kuma-moto, A.T. 30 (2): 152-160 (1978).

Nasalis larvatus

Untersuchungen am Hautleistensystem der Palma und Planta von Colobus poly-komos, Colobus badius, Colobus verus und Nasalis larvatus. Brehme, H. 6 (3-4): 243-283 (1967).

Über die Variabilität und Veränderungen der präbasialen Kyphose während der postnatalen Ontogenese bei Colobinen-schädeln. Angst, R. 8 (3-4): 301-306 (1968).

Colobus polykomos

Zur Kenntnis von Bau und Funktion des

Magens der Schlankaffen (Colobinae).

Kuhn, H.-J. 2 (4): 193-221 (1964). Kraniometrische Untersuchungen an Co-

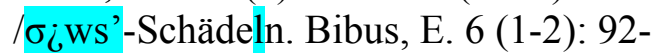

130 (1967). Die Mm. adductores femoris der niederen

Altweltaffen (Cercopithecidae). Uhl-

mann, K. 6 (1-2): 131-152 (1967). Untersuchungen am Hautleistensystem der

Palma und Planta von Colobus poly-

komos, Colobus badius, Colobus verus und Nasalis larvatus. Brehme, H. 6 (3-4): 243-283

(1967).

Über die Variabilität und Veränderungen der präbasialen Kyphose während der postnatalen

Ontogense bei Colobinen-schädeln. Angst, R. 8 (3-4): 301-306 (1968).

Contribution to the Ecology of Colobus polykomos satanas (Waterhouse, 1838) of Rio Muni,

Republic of Equatorial Guinea. SabaterPi, J. 19(2-3): 193-207 (1973).

Notes on the Ecology and Behaviour of the Angola Colobus (Colobus angolensis P.L. Sclater 1860 ) in N.E. Tanzania. Groves, C.P. 20 (1): 12-26 (1973).

Differential Habitat Utilization of Four Cercopithecidae in a Kenyan Forest. Moreno-Black,

G. and Maples, W. R. 27 (2): 85-107 (1977).

C. guereza

Vocalizations of East African Monkeys. I.

Red Colobus. Marler, P. 13 (2-3):

81-91 (1970). Ecology and Population Dynamics of

Colobus guereza in Ethiopia. Dunbar,

R.I.M. and Dunbar, E.P. $21\left(3^{\wedge} 1\right)$ :

188-208 (1974). Feeding Behaviour of Red Colobus and

Black and White Colobus in East Africa.

Clutton-Brock, T.H. 23 (3): 165-207

(1975).

C. verus

Zur Kenntnis von Bau und Funktion des 
Magens der Schlankaffen (Colobinae).

Kuhn, H.-J. 2 (4): 193-221 (1964). Kraniometrische Untersuchungen an Co-

lobus-Schädeln. Bibus, E. 6 (1-2): 92-

130(1967). Untersuchungen am Hautleistensystem der

Palma und Planta von Colobus poly-

Systematic Index

277

komos, Colobus badius, Colobus verus und Nasalis larvatus. Brehme, H. 6 (3-4): 243-283

(1967).

C. badius

Ein angeborener Unterkiefer-Defekt bei Procolobus badius badius (Kerr, 1792). Kuhn, H.-J. 1 (3-4): 172-177 (1963).

Zur Kenntnis von Bau und Funktion des Magens der Schlankaffen (Colobinae). Kuhn, H.-J. 2 (4): 193-221 (1964).

Kraniometrische Untersuchungen an Co-lobus-Schädeln. Bibus, E. 6 (1-2): 92-130 (1967).

Untersuchungen am Hautleistensystem der Palma und Planta von Colobus poly-komos,

Colobus badius, Colobus verus und Nasalis larvatus. Brehme, H. 6 (3^3/8): 243-283 (1967).

Vocalizations of East African Monkeys. I. Red Colobus. Marler, P. 13 (2-3): 81-91 (1970).

Feeding Levels and Feeding Sites of Red Colobus (Colobus badius tephrosceles) in the

Gombe National Park. Clutton-Brock, T.H. 19 (5): 368-379 (1973).

Activity Patterns of Red Colobus (Colobus badius tephrosceles). Clutton-Brock, T.H. 21 (3-

4): 161-187 (1974).

Feeding Behaviour of Red Colobus and Black and White Colobus in East Africa. ClottonBrock, T.H. 23 (3): 165-207 (1975).

Ein Fall von Einäugigkeit bei einem wild-lebenden Colobus b. badius. Himmel-heber, H. 26

(3): 227-228 (1976).

Hominoidea

Sulcus mylohyoideus, Foramen mandibulae und Sulcus retrotoralis bei Ponginen und

Hylobatiden. Vogel, C. 1 (2): 103-121 (1963).

On Color Vision in Gibbon and Orang-

utan. Tigges, J. 1 (3-4): 188-198 (1963).

Blood Groups of Apes and Monkeys. III. The M-N Blood Factors of Apes. Moor-Jankowski, J.; Wiener, A.S., and Gordon, E.B. 2 (3): 129-148 (1964).

Patterns of Parasitism in Primates: Phylo-genetic and Ecological Interpretations, with

Particular Reference to the Hominoidea. Dunn, F.L. 4 (5): 329-345 (1966).

Serum Transferrins of Pongidae: Pan, Pongo, and Hylobates. Nute, P. E. and Buettner-

Janusch, J. 8 (3-4): 282-289 (1968).

Respiratory Characteristics of the Blood of the Baboon, Gibbon, and Chimpanzee. Parer, J.T. and Moore, C.P. 9 (2): 154-159(1968).

Age Changes, Variability and Generic Differences in Body Proportions of Recent

Hominoids. Schultz, A.H. 19 (5): 338-359 (1973).

Sensory Nerve Terminations in the Oral Tissues of Some Pongidae. V $\pi$, S.;

Kanagasuntheram, R., and Krishna-murti, A. 20 (4): 312-320 (1973).

Distal Humerus in Hominoid Evolution. McHenry, H. M. and Corruccini, R. S. 23(3): 227244(1975). 
Affinities of Tertiary Hominoid Femora. McHenry, H. M. and Corruccini, R. S. 26(2): 139150(1976).

Hylobatidae

Sulcus mylohyoideus, Foramen mandibulae und Sulcus retrotoralis bei Ponginen und Hylobatiden. Vogel, C. 1 (2): 103-121 (1963).

Marked Chromosome in Catarrhine Monkeys. Chiarelli, B. 4 (1): 74-80 (1966).

Some Comparisons between Siamang and Gibbon Behaviour. Fox, G. J. 18 (1-2): 122139(1972).

Age Changes, Variability and Generic Differences in Body Proportions of Recent 278

A Topical Guide to 'Folia Primatologica'

Hominoids. Schultz, A.H. 19 (5): 338-359 (1973).

Long-Term Observations of Siamang Behaviour. Chivers, D.J.; Raemaekers, J.J., and Aldrich-Blake, F.P.G. 23 (1-2): 1-49 (1975).

The Influence of Selective Logging on Primates and some other Animals in East Kalimantan. Wilson, C.C and Wilson, W.L. 23 (4): 245-274 (1975).

Affinities of Tertiary Hominoid Femora. McHenry, H.M. and Corruccini, R.S. 26(2): 139150(1976).

Locomotion and Posture of the Malayan Siamang and Implications for Hominoid Evolution. Fleagle, J.G. 26 (4): 245-269 (1976).

Changes through the Day in the Food Choice of Wild Gibbons. Raemaekers, J. 30(3): 194205(1978).

Hylobates sp.

Marked Chromosome in Catarrhine Monkeys. Chiarelli, B. 4 (1): 74-80 (1966).

Geographic and Individual Variation in Bornean Gibbons, with Remarks on the Systematics of the Subgenus Hylobates. Groves, C.P. 14 (3-4): 139-153 (1971).

A Comparative Histochemical Study of the Mucins of the Nasal Fossa in Four Primates. Loo, S.K.; Kanagasuntheram, R., and Tocк, E.P.C. 17 (4): 275-284 (1972).

Some Comparisons between Siamang and Gibbon Behaviour. Fox, G.J. 18 (1-2): 122-139 (1972).

The Influence of Selective Logging on Primates and some other Animals in East Kalimantan. Wilson, C.C. and Wilson, W.L. 23 (4): 245-274 (1975).

H.lar

On Color Vision in Gibbon and Orangutan. Tigges, J. 1 (3-4): 188-198 (1963).

Blood Groups of Apes and Monkeys. III.

The M-N Blood Factors of Apes.

Moor-Jankowski, J.; Wiener, A.S., and Gordon, E.B. 2 (3): 129-148 (1964). The Activity of Gibbons in a Social Group.

Bernstein, I. S and Schusterman, R. J.

2(3): 161-170(1964). Geburt und frühe Entwicklung zweier Gibbons (Hylobates lar L.) Ibscher, L.

5 (1-2): 43-69 (1967). Intertaxa Interactions in a Malayan Primate

Community. Bernstein, I.S. 7 (3-4):

198-207 (1967). Serum Transferrins of Pongidae: Pan,

Pongo, and Hylobates. Nute, P.E. and 
Buettner-Janusch, J. 8 (3-4): 282-289

(1968). Respiratory Characteristics of the Blood of

the Baboon, Gibbon, and Chimpanzee.

Parer, J.T. and Moore, C.P. 9 (2):

154-159(1968). Locomotion and Posture of the Malayan

Siamang and Implications for Hominoid

Evolution. Fleagle, J.G. 26 (4): $245-$

269 (1976). Genetic Variation of Aldehyde Dehydro-

genase in Primates. Friedrichson, U.;

Ritter, H., and Schmitt, J. 29 (2):

95-97 (1978). Changes through the Day in the Food

Choice of Wild Gibbons. Raemaekers, J.

30 (3): 194-205 (1978).

H.pileatus

The Activity of Gibbons in a Social Group. Bernstein, I.S. and Schusterman, R. J. 2(3): 161170(1964).

H. agilis

A Comparative Study of the Nasal Fossa of Four Nonhuman Primates. Loo, S.K. 20 (5-6):

410-422 (1973).

Systematic Index

279

Comparative Study of the Histology of the Nasal Fossa in Four Primates. Loo, S. K. 21 (3-4): 290-303 (1974).

Locomotion and Posture of the Malayan Siamang and Implications for Hominoid Evolution. Fleagle, J.G. 26 (4): 245-269 (1976).

H. hoolock

Geographic Variation in the Hoolock or White-Browed Gibbon \{Hylobates hoolock Harlan, 1834J. Groves, C.P. 7 (3-4): 276-283, (1967).

H. klossii

Preliminary Observations of the Mentawai Islands Gibbon, Hylobates klossii. Tenaza, R. R. and Hamilton in, W. J. 15 (3-4): 201-211 (1971).

Territory and Monogamy Among Kloss' Gibbons (Hylobates klossii) in Siberut Island, Indonesia. Tenaza, R.R. 24 (1): 60-80(1975).

Symphalangus syndactylus

Craniopharyngeal Canal and Pharyngeal Hypophysis in the Siamang Gibbon (Symphalangus syndactylus). Leela, K. and Kanagasuntheram, R. 14 (1-2): 118-122(1971).

Polydactylism in a Siamang. Schultz, A. H. 17 (4): 241-247 (1972).

Some Comparisons between Siamang and Gibbon Behaviour. Fox, G. J. 18 (1-2): 122-139 (1972).

Sensory Nerve Terminations in the Oral Tissues of Some Pongidae. Vu, S.;

Kanagasuntheram, R., and Krishna-murti, A. 20 (4): 312-320 (1973).

Long-Term Observations of Siamang Behaviour. Chyvers, D.J.; Raemaekers, J.J., and Aldrich-Blake, F.P.G. 23 (1-2): 1-3/89 (1975).

Pongidae 
Sulcus mylohyoideus, Foramen mandibulae und Sulcus retrotoralis bei Ponginen und Hylobatiden. Vogel, C. 1 (2): 103-121 (1963).

Les chances primatologiques de l'Est-Africain. Bone, E.L. 2 (1): 1-21 (1964).

Blood Groups of Apes and Monkeys. III. The M-N Blood Factors of Apes. Moor-Jankowski, J.; Wiener, A.S., and Gordon, E.B. 2 (3): 129-148 (1964).

Serum Transferrins of Pongidae: Pan, Pongo, and Hylobates. Nute, P. E. and BuettnerJanusch, J. 8 (3-4): 282-289 (1968).

Observation on Growth Structure of the Nail in Hominoidea. Sprankel, H. 10 (3): 161-171 (1969).

Studies on Folate and Vitamin B12 Metabolism in Primates. I. Blood and Bone Marrow Morphology, Folate and Vitamin B12 Levels. Huser, H.-J. and Beard, M.E.J. 10 (3): 172-180 (1969).

Studies on Folate and Vitamin B12 Metabolism in Primates. II. Vitamin B12 Binding

Proteins. Beard, M.E.J. and Huser, H.-J. 12 (4): 305-312 (1970).

Haptoglobins in Chimpanzees and Gorillas. Planas, J. 13 (2-3): 177-182 (1970).

Serum Chemistry in the Chimpanzee and the Gorilla. Planas, J. and Grau, M.:

15 (1-2): 77-87 (1971).

The Contrasting Morphology Found in the Wrist Joints of Semibrachiating Monkeys and Brachiating Apes. Lewis, O. J.

$16 \quad\left(3^{\wedge} 1\right): 248-256(1971)$.

Creative Responsiveness to Objects: A Report of a Pilot Study with Young

280

A Topical Guide to 'Folia Primatologica'

Apes. Rumbaugh, D. M.; Riesen, A. H., and Wright, S.C. 17 (5-6): 397-403 (1972).

On the Corpus adiposum buccae (Bichat) in Pan troglodytes. Hofer, H.O. 17 (5-6): 434-441

(1972).

A Comparative Study on the Oro-Nasal Region of the External Face of the Gorilla as a Contribution to Cranio-Facial Biology of Primates. Hofer, H. O. 18 (5-6): 416-432 (1972).

Age Changes, Variability and Generic Differences in Body Proportions of Recent Hominoids. Schultz, A.H. 19 (5): 338-359 (1973).

Blood Group Homologues in Orangutans and Gorillas of the Human Rh-Hr and the Chimpanzee C-E-F Systems. Moor-Jankowski, J.; Wiener, A.S.; Socha, W.W.; Gordon, E.B., and Kaczera, Z. 19 (5): 360-367 (1973).

Finger- und Zehenbeerenmuster von Pon-giden. Brehme, H. und Wiersema, H. D. 20 (5-6): 391-409 (1973).

New Data and a Discussion of Infant Killing in Old World Monkeys and Apes. Angst, W. and Thommen, D. 27 (3): 198-229 (1977).

Chimpanzee Simian-Type Blood Groups: Reproducibility of Formerly Described Antisera and Demonstration of New Blood Groups $\mathrm{O}^{\circ}$ and Pcla. Moor-Jankowski, J.; Socha, W. W.; Wiener, A.S., and Plonski, H. 28 (3): 216-230 (1977).

Pongo pygmaeus

On Color Vision in Gibbon and Orang-Utan. Tigges, J. 1 (3-4): 188-198 (1963).

Size and Distance of Food: Cues Influencing the Choise Behavior of Orangutans (Pongo pygmaeus). Draper, W. A. and Menzel, E.W., jr.4(3): 186-190(1966).

The Orang-Utan in Sabah. Davenport, R. K.,jr. 5 (4): 247-263 (1967). 
Observation on Growth Structure of the Nail in Hominoidea. Sprankel, H. 10 (3): 161-171

(1969).

Bornean Orang-Utan Twins Born in Captivity. Heinrichs, W.L. and Dilling-ham, L. A. 13 (23): 150-154 (1970).

Luteinizing Hormone Levels in Nonhuman Primates. Blakley, G. A. 13 (4) 298-305 (1970).

The Contrasting Morphology Found in the Wrist Joints of Semibrachiating Monkeys and Brachiating Apes. Lewis, O. J. 16 (3-4): 248-256 (1971).

Creative Responsiveness to Objects: A Report of a Pilot Study with Young Apes. Rumbaugh, D. M.; Riesen, A.H., and Wright, S.C. 17 (5-6): 397-403 (1972).

Hematologic and Blood Chemistry Data for the Orangutan (Pongo pygmaeus). McClure,

H.M.; Keeling, M.E., and Guilloud, N.B. 18 (3-4): 284-299 (1972):

Sensory Nerve Terminations in the Oral Tissues of Some Pongidae. Vu, S.;

Kanagasuntheram, R., and Krishna-murti, A. 20 (4): 312-320 (1973).

Beobachtungen zum Schwangerschafts- und Geburtsverhalten beim Orang-Utan (Pongo

pygmaeus) im Tierpark Berlin. Lippert, W. 21 (2): 108-134 (1974).

The Influence of Selective Logging on Primates and some other Animals in East Kalimantan. Wilson, C.C. and Wilson, W.L. 23 (4): 245-274 (1975).

Agonistic Interactions of Captive Female Orang-Utans with Infants. Nadler, R. D. and

Tilford, B. L. 28 (4): 298-305 (1977).

Pan troglodytes

An Outline of the Behaviour and Social Organisation of Forest-Living Chimpanzees.

Reynolds, V. 1 (2): 95-102 (1963).

Systematic Index

281

Some Notes on the Distribution of Primates in the Sudan. Butler, H. 4 (6): 416-423 (1966).

Conditioning of a Vocal Response in a Chimpanzee through Social Reinforcement.

Randolph, M.C. and Brooks, B.A. 5 (1-2): $70-79$ (1967).

Beobachtungen an dem sogenannten «Su-pracommissuralen Organ» (Fuse) und am Recessus mesocoelicus der Primaten. Hofer, H. 5 (3): 190-200 (1967).

Baseline Blood Values of the Chimpanzee.

I. The Relationship of Age and Sex and

Haematological Values. Hodson, H.H.,

jr.; Lee, B.D.; Wisecup, W.G., and

Fineg, J. 7(1): 1-11 (1967).

Baseline Blood Values of the Chimpanzee.

II. The Relationship of Age and Sex

and Serum Chemistry Values. Hodson,

H.H., jr.; Wisecup, W.G.; Faulkner,

M.F., and Felts, P.E. 8 (1): 77-86

(1968).

Respiratory Characteristics of the Blood of the Baboon, Gibbon, and Chimpanzee. Parer, J.T. and Moore, C. P. 9 (2): 154-159 (1958).

Effects of Rearing Conditions on Distress Vocalizations in Chimpanzees. Randolph, M.C.

and Mason, W.A. 10 (1-2): 103-112(1969). 
Observation on Growth Structure of the Nail in Hominoidea. Sprankel, H. 10 (3): 161-171 (1969).

The Glandula Apicis Linguae in Pan troglodytes. Hofer, H. 0.12 (1): 38-41 (1970).

The Development of Tool Using in Wild-Born and Restriction-Reared Chimpanzees. Menzel, E.W., jr.; Davenport, R.K., and Rogers, CM. 12 (4): 273-283 (1970).

Sleep of Unrestrained Chimpanzee: Differences Between First and Last Rapid Eye Movement Periods. Freemon, F.R.; McNew, J. J., and Adey, W. R. 13 (2-3): 144-149 (1970). Haptoglobins in Chimpanzees and Gorillas. Planas, J. 13 (2-3): 177-182(1970).

Water-Contact Behavior of Chimpanzees. Angus, S. 14 (1-2): 51-58 (1971). Intrarenal Arterial Patterns in Nonhuman Primates. Stinson, J. M. 14 (1-2): $70-79$ (1971). On the Existence of Currently Described Subspecies in the Chimpanzee (Pan troglodytes). Reynolds, V. and Lus-combe, G. 14 (3-^): 129-138 (1971).

Serum Chemistry in the Chimpanzee and the Gorilla. Planas, J. and Grau, M. 15 (1-2): 77-87 (1971).

Hydronephrosis of Pregnancy: a Naturally Occurring Disorder in Non-Human Primates Closely Resembling that in Man. Roberts, J.A. and Wolf, R.H. 15(1-2): 143-147(1971).

Evidence of Tool-Using by Chimpanzees in the Ivory Coast. Struhsaker, T.T. and Hunkeler, P. 15 (3-4): 212-219 (1971).

Communication about the Environment in a Group of Young Chimpanzees. Menzel, E.W., jr. 15 ( $\left.3^{\wedge} 1\right): 220-232$ (1971).

On the Recessus Mesocoelicus in some Primates. Hofer, H.O. 15 (3-4): 249-263 (1971).

Spontaneous Invention of Ladders in a Group of Young Chimpanzees. Menzel, E.W., jr. 17 (1-2): 87-106 (1972).

Protocultural Aspects of Chimpanzees' Responsiveness to Novel Objects. Menzel, E.W., jr.; Davenport, R.K., and Rogers, CM. 17 (3): 161-170 (1972).

Creative Responsiveness to Objects: a Report of a Pilot Study with Young Apes. Rumbaugh, D. M.; Riesen, A.H., and Wright, S.C 17 (5-6): 397^103 (1972).

On the Corpus adiposum buccae (Bichat) in Pan troglodytes. Hofer, H. 0.17 (5-6:) 434-441 (1972).

Note on Blonde Chimpanzee. Rosen, S.I.; Rich, K., and Ommaya, A.K. 18 (1-2): 41-46 (1972).

A Comparative Study on the Oro-Nasal Region of the External Face of the 282

A Topical Guide to 'Folia Primatologica'

Gorilla as a Contribution to Cranio-Facial Biology of Primates. Hofer, H. O. 18 (5-6): 416432 (1972).

Hematologic and Blood Chemistry Data for the Chimpanzee (Pan troglodytes). McClure, H.M.; Keeling, M.E., and Guylloud, N.B. 18 (5-6): 444-462 (1972).

Chimpanzee Copulatory Behaviour. Tutin, C.E.G and McGrew, W.C.: 19 (4): 237-256

(1973).

Further Observations on the Use of Ladders in a Group of Young Chimpanzees. Menzel, E.W., jr. 19 (6): 450-457 (1973).

Chimpanzee Endometrium and Sexual Swelling during Menstrual Cycle or Hormone Administration. Graham, C. E. 19 (6): 458-468 (1973). 
Crista sagittalis externa in the Skull of Pan troglodytes and Its Bearing on the Reconstruction of the Head of the Robust Type of Australopithecus. Hofer, H.0.19 (6): 469-475 (1973).

Group Response to the Accidental Death of a Chimpanzee in Gombe National Park, Tanzania. Teleki, G. 20 (2-3): 81-94 (1973).

Group Formation among Captive Mother-Infant Chimpanzees (Pan troglodytes). Savage, E.S.; Temerlin, J.W., and Lemmon, W.B. 20 (5-6): 453-473 (1973).

Chorionic Gonadotrophin in the Placenta of a Chimpanzee (Pan troglodytes). Hobson, B. M. 23 (1-2): 135-139 (1975).

Weight Growth of Colony-Reared Chimpanzees. Smith, A.H.; Butler, T.M., and Pace, N. 24 (1): 29-59 (1975).

Sleeping Behavior and Associations in a Group of Captive Chimpanzees. Riss, D. and Goodall, J. 25 (1): 1-11 (1976).

The Bark-Eating Habits in Primates, with Special Reference to Their Status in the Diet of Wild Chimpanzees. Nishida, T. 25 (4): 277-287 (1976).

Erythroblastosis Models. II. Materno-Fetal Incompatibility in Chimpanzee. Wiener, A.S.; Socha, W.W., and Moor-Jankowski, J. 27 (1): 68-74 (1977).

The Recent Rise to the Alpha-Rank in a Population of Free-Living Chimpanzees. Riss, D. and Goodall, J. 27 (2): 134-151 (1977).

New Data and a Discussion of Infant Killing in Old World Monkeys and Apes. Angst, W. and Thommen, D.:

27 (3): 198-229 (1977).

Competition for Meat between Chimpan

zees and Baboons of the Gombe Natio

nal Park. Morris, K. and Goodall, J.

28 (2): 109-121 (1977).

Chimpanzee Simian-Type Blood Groups:

Reproducibility of Formerly Described Antisera and Demonstration of New Blood Groups $0^{\circ}$ and Pcla. Moor-Jankowski, J.; Socha, W. W.; Wiener, A.S., and Plonski, H. 28 (3): 216-230 (1977).

Infant Killing and Cannibalism in Free-Living Chimpanzees. Goodall, J. 28 (4): 259-282 (1977).

Fifty-Day Observation of a Free-Ranging Adult Male Chimpanzee. Riss, D.C. and Busse, CD. 28 (4): 283-297 (1977).

Skeletal Differences between Pygmy (Pan paniscus) and Common Chimpanzees (Pan troglodytes). Z $\gamma$ hlman, A.L. and Cramer, D.L. 29 (2): 86-94 (1978).

Patterns of Food Sharing among Mother and Infant Chimpanzees at Gombe National Park, Tanzania. Silk, J.B. 29(2): 129-141 (1978).

Map Reading by Chimpanzees. Menzel, E. W., jr.; Premack, D., and Woodruff, G. 29 (4): 241-249 (1978).

Continual Sexual Receptivity in the Female Chimpanzee (Pan troglodytes). Lemmon, W.B. and Allen, M.L. 30 (1): 80-88 (1978).

Systematic Index

283

\section{P.paniscus}

On the Identity of the Ape Described by Tulp 1641. Reynolds, V. 5 (1-2): $80-87$ (1967). 
On the Existence of Currently Described Subspecies in the Chimpanzee (Pan troglodytes). Reynolds, V. and Lus-combe, G. 14 (3-4): 129-138 (1971).

Chromosomal Analysis of the Pygmy Chimpanzee (Panpaniscus) with a Comparison to Man. Bogart, M.H. and Benirschke, K. 27 (1): 60-67 (1977).

Chimpanzee Simian-Type Blood Groups: Reproducibility of Formerly Described Antisera and Demonstration of New Blood Groups $0^{\circ}$ and Pcla. Moor-Jankowski, J.; Socha, W. W.; Wiener, A.S., and Plonski, H. 28 (3): 216-230 (1977).

Skeletal Differences between Pygmy (Pan paniscus) and Common Chimpanzees (Pan troglodytes). Zihlman, A.L. and Cramer, D. L. 29 (2): 86-94 (1978).

Gorilla gorilla

A Gorilla with Exceptionally Large Teeth and Supernumerary Premolars. Schultz, A.H. 2 (3) 149-160 (1965)

The Idiogram of the Lowland Gorilla (Gorilla gorilla gorilla). Egozcue, J. and Chiarelli, B. 5 (3): 237-240 (1967).

Spontaneous Hyperthermia in the Gorilla. Guilloud, N.B. and Fitz-Gerald, F. L. $6(3-4)$ : 177179 (1967).

An Albino Lowland Gorilla from Rio Muni, West Africa, and Notes on its Adaptation to Captivity. Sabater Pi, J. 7 (2): 155-160(1967).

Food Preferences in Lowland Gorillas. Fitz-Gerald, F.L.; Barfyeld, M.A., and Grubbs, P.A. 12 (3): 209-211 (1970).

Haptoglobins in Chimpanzees and Gorillas.

Planas, J. 13 (2-3) 177-182 (1970).

Anomaly of the Hallux in a Lowland Gorilla (Gorilla gorilla gorilla Savage and WymanJ.

Hill, W.C.O. and Sabater Pi, J. 14 (3^t): 252-255 (1971).

Serum Chemistry in the Chimpanzee and the Gorilla. Planas, J. and Grau, M. 15(1-2:7787(1971).

Pulmonary Embolus and Testicular Atrophy in a Gorilla. Antonius, J.I.; Ferrier, S.A., and Dillingham, L.A.

15 (3-4): 277-292 (1971).

Discrimination Reserval Skills of the Low

land Gorilla (Gorilla g. gorilla). Rum-

baugh, D.M. and Steinmetz, G.T. 16

(1-2): 144-152(1971).

The Contrasting Morphology Found in the Wrist Joints of Semibrachiating Monkeys and Brachiating Apes. Lewis, O. J.

16 (3-4): 248-256 (1971)

Twin Gorilla Fetuses. Rosen, S.I. 17 (1-2):

132-141 (1972). On the Corpus adiposum buccae (Bichat) in

Pan troglodytes. Hofer, H.O. 17 (5-6):

434-441 (1972). Hematologic and Blood Chemistry Data

for the Gorilla (Gorilla gorilla). Mc-

Clure, H.M.; Keeling, M.E., and

Guilloud, N.B. $18\left(3^{\wedge} 1\right): 300-316$

(1972). Growth Fields in the Dentition of the

Gorilla. Suarez, B.K. and Bernor, R.

18(5-6): 356-367(1972). A Comparative Study on the Oro-Nasal 
Region of the External Face of the

Gorilla as a Contribution to Cranio-

Facial Biology of Primates. Hofer, H. O.

18(5-6): 416-432 (1972). Feeding Ecology and Nutrition of an

Eastern Gorilla Group in the Mt.

Kahuzi Region (République du Zaire).

Casimir, M.J. 24 (2-3): 81-136 (1975). Observations on a Small Group of Mountain Gorillas

(Gorilla gorilla beringei).

Elliott, R.C. 25 (1): 12-24 (1976). New Data and a Discussion of Infant

Killing in Old World Monkeys and

A Topical Guide to 'Folia Primatologica'

284

Apes. Angst, W. and Thommen, D. 27 (3): 198-229 (1977).

Neue Beobachtungen und Überlegungen zur Pathologie des Primatenschädels. Ein Beitrag zur 'Gundu'-Frage. Schultz, M. und Starck, D. 28 (2): 81-108 (1977).

Status Interactions of Captive Female Lowland Gorillas. Fischer, R.B. and Nadler, R.D. 28 (2): 122-133 (1977).

Chimpanzee Simian-Type Blood Groups: Reproducibility of Formerly Described Antisera and Demonstration of New Blood Groups Oc and Pcia. Moor-Jan-kowski, J.; Socha, W.W.; Wiener, A.S., and Plonski, H. 28 (3): 216-230 (1977).

Male Parental Behavior in a Captive Group of Lowland Gorillas (Gorilla gorilla gorilla).

Tilford, B. L. and Nadler, R. D. 29 (3): 218-228 (1978).

Fossil primates

Archaic primates

Paleontology and the Origin of the Primates.

McKenna, M.C. 4 (1): 1-25 (1966). The Paleocene Primate Plesiolestes and the

Origin of Microsyopidae. Bown, T. M.

andGingerich,P.D. 19(1): 1-8): (1973). New Paleocene Primates and a Diagnosis

of the New Suborder Paromomyiformes.

Szalay, F.S. 19 (2-3): 73-87 (1973). A New Species and Genus of Early Eocene

Primate from North America. Szalay,

F.S. 22 (4): 243-250 (1974). Where to Draw the Nonprimate-Primate

Taxonomic Boundary. Szalay, F.S.

23 (1-2): 158-163 (1975). New Early Tertiary Primates and a Reappraisal of some

Plesiadapiformes.

Bown, Th.M. and Rose, K.D. 26 (2):

109-138 (1976).

Lemuriformes Adapidae

New Prosimian Remains from Early Tertiary Deposits of Southern England. Day, M. H. and Walker, A. C. 10 (1-2): 139-145 (1969).

New Genera of European Eocene Adapid Primates. Szalay, F.S. 22 (2-3): 116-133 (1974).

New Adapid Primate of European Affinities from Texas. Wilson, J.A. and Szalay, F.S. 25 (4): 294-312 (1976).

New Species of Eocene Primates and the Phylogeny of European Adapidae. Gingerich, P.D. 28 (1): 60-80 (1977).

Subfossil malagachian primates 
Lebensbild von Megaladapis edwardsi (Grandidier). Ein Rekonstruktionsversuch. Zapfe, H. 1 (3-4): 178-187 (1963). Die pathologischen Veränderungen am

Unterkiefer von Megaladapis edwardsi

G. Grandidier. Zenker, A. 3 (1): 75-80

(1965). Revision of the Subfossil Indriinae. Tatter-

sall, I. 16 (3-4): 257-269 (1971). The Functional Significance of Airorhynchy

in Megaladapis. Tattersall, 1.18 (1-2):

20-26 (1972). Re-Evaluation of the Morphocline of Molar

Appearance in the Primates. Schwartz,

J.H. 23 (4): 290-307 (1975).

Tarsiiformes

A New Primate from the Earliest Oligocene, West Texas. Preliminary Report. Wn $>$ son, J.A. 4 (3): 227-248 (1966).

An Endocranial Cast of an Early Oligocene Primate. Hofer, H. O. and Wilson, J. A. 5(1-2): 148-152(1967).

Phylogeny of Lemurs, Galagos and Lorises

Systematic Index

285

Szalay, F.S. and Katz, C.C. 19 (2-3): 88-103 (1973).

Affinities of Teilhardina (Primates, Omo-mydae) with Description of a New Species from North America. Bown, T. M. 25(1): 62-72 (1976).

Basicranial Morphology of the Early Tertiary Tarsiiform Rooneyia from Texas. Szalay, F.S. and Wilson, J. A. 25 (4): 288-293 (1976).

Dental Variation in Early Eocene Teilhardina belgica, with Notes on the Anterior Dentition of Some Early Tar-siiformes. Gingerich, P. D. 28 (2): 144-153 (1977).

A New Omomyid Primate from the Wasatch Formation of Southern Wyoming. Savage, D.E. and Waters, B.T. 30 (1): 1-29 (1978).

Platyrrhina

Notes on Tertiary Platyrrhine Monkeys and Description of a New Genus from the Late Miocene of Colombia. Hershko-vitz, P. 12(1): 1-37(1970).

A New Genus of Late Oligocene Monkey (Cebidae, Platyrrhini) with Notes on Postorbital

Closure and Platyrrhine Evolution. Hershkovitz, P. 21 (1): 1-35 (1974).

Catarrhina

Cercopithecidae

New Fossil Cercopithecus Material from the Lower Omo Basin, Ethiopia. Eck, G. and Howell, F. C. 18 (5-6): 325-355 (1972).

Oreopithecidae Observations on the Acetabulum of Pri-

mates. Schultz, A.H. 11 (3): 181-199 (1969). Rumpfskelettlänge, Allometrien und Körperproportionen bei catarrhinen Pri-maten. Biegert, J. und Maurer, R. 17 (1-2): 142156(1972).

Parapithecidae

Anatomy of the Temporal Bone in the

Oligocene Anthropoid Apidium and the

Origin of Anthropoidea. Gingerich, P. 
D. 19 (5): 329-337 (1973). The Ectotympanic Bone and Origin of

Higher Primates. Hershkovitz, P. 22

(4): 237-242 (1974). Dental Eruption Patterns in Parapithecidae

(Primates, Anthropoidae). Conroy, G.

C; Schwartz, J.H., and Simons, E.L.

24 (4): 275-281 (1975).

Hylobatidae

Rumpfskelettlänge, Allometrien und Kör-perproportionen bei catarrhinen Pri-maten. Biegert, J. und Maurer, R. 17 (1-2): 142-156(1972).

Osteometric Shape Relationship in the Wrist Joint of Some Anthropoids. Corruccini, R. S.;

Ciochon, R. L., and McHenry, H.M. 24 (4): 250-274 (1975).

Dryopithecidae

A Reconstruction of the Skull of Proconsul africanus (R. S. 51). Davis, P.R. and Napier, J. 1 (1): 20-28 (1963).

A Gorilla with Exceptionally Large Teeth and Supernumerary Premolars. Schultz, A.H. 2 (3): 149-160 (1964).

Preliminary Revision of the Dryopithecinae

286

A Topical Guide to 'Folia Primatologica'

(Pongidae, Anthropoidea). Simons, E. L. and Pilbeam, D.R. 3 (2-3): 81-152 (1965).

Ein weiterer Zahn von Dryopithecus (Dry.) fontani darwini Abel, 1902 (Mammalia,

Pongidae) aus dem Miozän des Wiener Beckens. Steininger, F. 7 (3-4): 243-275 (1967).

Notes on Some Little-Known Primate Fossils from India. Tattersall, I. M. and Simons, E.L. 10 (1-2): 146-153 (1969).

Critical Observations on the Fossil Anthropoids from the Siwalik System of India. Prasad, K.N. 10 (4): 288-317 (1969).

Wrist Mechanism and Locomotor Behavior of Dryopithecus (Proconsul) africanus. Schön, M. A. and Ziemer, L.K. 20 (1): 1-11 (1973).

Note on the Placement of the Most Complete tKenyapithecus africanus'' Mandible.

Greenfield, L. 0.20 (4): 274-279 (1973).

Laxonomic Reassessment of Two Ramapi-thecus Specimens. Greenfield, L.O. 22 (2-3)97115(1974).

A Small Gibbon-Like Hominoid from the Miocene of Uganda. Fleagle, J.G. 24 (1): 115(1975).

Osteometric Shape Relationship in the Wrist Joint of Some Anthropoids. Corruccini, R. S.;

Ciochon, R. L., and McHenry, H.M. 24 (4): 250-274 (1975).

Affinities of Tertiary Hominoid Femora. McHenry, H.M. and Corruccini, R. S. 26(2): 139150(1976).

Non-Metric Features in the Ulna of Aegyptopithecus, Alouatta, Ateles, and Lagothrix. Schön Ybarra, M.A. and Conroy, G.C. 29 (3): 178-195 (1978).

Restoration of the Holotype of Proconsul nyanzae. Whybrow, P. J. and Andrews, P. 30(2): 115-125(1978).

Hominidae Australopithecinae

Observations on the Acetabulum of Primates. Schultz, A.H. 11 (3): 181-199 (1969). 
Body Posture and Mode of Locomotion in Early Pleistocene Hominids. Preu-schoft, H. 14 (34): 209-240 (1971).

Rumpfskelettlänge, Allometrien und Kör-perproportionen bei catarrhinen Pri-maten. Biegert, J. und Maurer, R. 17 (1-2): 142-156(1972).

A Biochemical Interpretation of the Pelvis of Australopithecus. Zihlman, A. L. and Hunter, W.S. 18 (1-2): 1-19 (1972)

Encephalization in Australopithecines: a New Estimate. Leutenegger, W. 19 (1): 9-17 (1973). Crista sagittalis externa in the Skull of Pan troglodytes and Its Bearing on the Reconstruction of the Head of the Robust Type of Australopithecus. Ho-fer, H.0.19 (6): 469-475 (1973).

Distal Humerus in Hominoid Evolution. McHenry, H. M. and Corruccini, R. S. 23 (3): 227244 (1975). 